\title{
Resilience of Microbial Communities after Hydrogen Peroxide Treatment of a Eutrophic Lake to Suppress Harmful Cyanobacterial Blooms
}

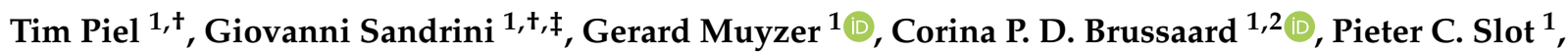 \\ Maria J. van Herk ${ }^{1}$, Jef Huisman ${ }^{1}$ D and Petra M. Visser ${ }^{1, *(D)}$
}

1 Department of Freshwater and Marine Ecology, Institute for Biodiversity and Ecosystem Dynamics, University of Amsterdam, 1090 GE Amsterdam, The Netherlands; t.f.piel@uva.nl (T.P.); giovanni.sandrini@gmail.com (G.S.); g.muijzer@uva.nl (G.M.); corina.brussaard@nioz.nl (C.P.D.B.); p.c.slot@uva.nl (P.C.S.); m.j.vanherk@uva.nl (M.J.v.H.); j.huisman@uva.nl (J.H.)

2 Department of Marine Microbiology and Biogeochemistry, NIOZ Royal Netherland Institute for Sea Research, 1790 AB Den Burg, The Netherlands

* Correspondence: p.m.visser@uva.nl; Tel.: +31-20-5257073

+ These authors have contributed equally to this work.

$\ddagger$ Current address: Department of Technology \& Sources, Evides Water Company, 3006 AL Rotterdam, The Netherlands.

Citation: Piel, T.; Sandrini, G.; Muyzer, G.; Brussaard, C.P.D.; Slot, P.C.; van Herk, M.J.; Huisman, J.;

Visser, P.M. Resilience of Microbial Communities after Hydrogen

Peroxide Treatment of a Eutrophic Lake to Suppress Harmful Cyanobacterial Blooms. Microorganisms 2021, 9, 1495. https://doi.org/10.3390/ microorganisms 9071495

Academic Editor: Aaron Kaplan

Received: 21 May 2021

Accepted: 9 July 2021

Published: 13 July 2021

Publisher's Note: MDPI stays neutral with regard to jurisdictional claims in published maps and institutional affiliations.

Copyright: (c) 2021 by the authors. Licensee MDPI, Basel, Switzerland. This article is an open access article distributed under the terms and conditions of the Creative Commons Attribution (CC BY) license (https:// creativecommons.org/licenses/by/ $4.0 /)$.
Abstract: Applying low concentrations of hydrogen peroxide $\left(\mathrm{H}_{2} \mathrm{O}_{2}\right)$ to lakes is an emerging method to mitigate harmful cyanobacterial blooms. While cyanobacteria are very sensitive to $\mathrm{H}_{2} \mathrm{O}_{2}$, little is known about the impacts of these $\mathrm{H}_{2} \mathrm{O}_{2}$ treatments on other members of the microbial community. In this study, we investigated changes in microbial community composition during two lake treatments with low $\mathrm{H}_{2} \mathrm{O}_{2}$ concentrations (target: $2.5 \mathrm{mg} \mathrm{L}^{-1}$ ) and in two series of controlled lake incubations. The results show that the $\mathrm{H}_{2} \mathrm{O}_{2}$ treatments effectively suppressed the dominant cyanobacteria Aphanizomenon klebahnii, Dolichospermum sp. and, to a lesser extent, Planktothrix agardhii. Microbial community analysis revealed that several Proteobacteria (e.g., Alteromonadales, Pseudomonadales, Rhodobacterales) profited from the treatments, whereas some bacterial taxa declined (e.g., Verrucomicrobia). In particular, the taxa known to be resistant to oxidative stress (e.g., Rheinheimera) strongly increased in relative abundance during the first $24 \mathrm{~h}$ after $\mathrm{H}_{2} \mathrm{O}_{2}$ addition, but subsequently declined again. Alpha and beta diversity showed a temporary decline but recovered within a few days, demonstrating resilience of the microbial community. The predicted functionality of the microbial community revealed a temporary increase of anti-ROS defenses and glycoside hydrolases but otherwise remained stable throughout the treatments. We conclude that the use of low concentrations of $\mathrm{H}_{2} \mathrm{O}_{2}$ to suppress cyanobacterial blooms provides a short-term pulse disturbance but is not detrimental to lake microbial communities and their ecosystem functioning.

Keywords: cyanobacterial blooms; 16S rRNA gene amplicon sequencing; hydrogen peroxide; microbial community; microbial diversity; resilience; ecosystem functioning; oxidative stress; lake treatment

\section{Introduction}

Harmful cyanobacterial blooms often occur in eutrophic freshwater ecosystems, causing degradation of water quality and possibly ecological and economic disruption [1-4]. Many bloom-forming cyanobacteria can produce toxins which harm animals such as fish, birds and mammals, including humans, either directly after ingestion of contaminated water or indirectly via the food chain [5-8]. The widespread increase of harmful cyanobacterial blooms around the globe has been linked to eutrophication and climate change [9-12].

The most effective and most preferred long-term method to reduce cyanobacterial blooms is reduction of nutrient inputs into the water body $[13,14]$. Due to the difficulties in 
managing catchment nutrient loads [15] and internal nutrient loading from the sediment of lakes [16], it often takes a long time before nutrient reduction measures result in a decrease of cyanobacterial abundances. Hence, there is an increased interest in shortterm methods to rapidly suppress cyanobacterial blooms that can complement long-term nutrient reduction strategies $[4,17,18]$.

Addition of hydrogen peroxide $\left(\mathrm{H}_{2} \mathrm{O}_{2}\right)$ to lakes is a promising method for rapid mitigation of cyanobacterial blooms because cyanobacteria are more sensitive to low concentrations of $\mathrm{H}_{2} \mathrm{O}_{2}$ than most eukaryotic organisms [19-26]. Furthermore, $\mathrm{H}_{2} \mathrm{O}_{2}$ is a naturally occurring compound that degrades into water and oxygen, and hence, unlike other algicides, the added $\mathrm{H}_{2} \mathrm{O}_{2}$ disappears within a few days [27]. The high sensitivity of cyanobacteria to $\mathrm{H}_{2} \mathrm{O}_{2}$ in comparison to eukaryotic phytoplankton can likely be attributed to differences in the Mehler reaction. In eukaryotic organisms, photosynthesis can lead to the production of reactive oxygen species (ROS) such as $\mathrm{O}_{2}{ }^{-}$and $\mathrm{H}_{2} \mathrm{O}_{2}$, which are subsequently converted to water by peroxidases and catalases to protect cells against oxidative stress [28,29]. In cyanobacteria, the transfer of excess electrons generated by photosynthesis is mediated by flavodiiron proteins which produce water without the formation of $\mathrm{O}_{2}{ }^{-}$or $\mathrm{H}_{2} \mathrm{O}_{2}$ [30,31]. Accordingly, cyanobacteria produce less $\mathrm{H}_{2} \mathrm{O}_{2}$ during photosynthesis, and hence they tend to be much less protected against $\mathrm{H}_{2} \mathrm{O}_{2}$ than eukaryotic phytoplankton $[25,27]$.

Effects of $\mathrm{H}_{2} \mathrm{O}_{2}$ on cyanobacteria have been investigated mainly in small-scale laboratory experiments [32-40], mesocosms and pond experiments [21-24,26,41,42]. Only a few studies have investigated $\mathrm{H}_{2} \mathrm{O}_{2}$ treatments of entire lakes, reporting the impact on cyanobacteria, eukaryotic phytoplankton, zooplankton and macroinvertebrates at the ecosystem scale [25,43-45]. Generally, these studies show that cyanobacteria are indeed much more sensitive to $\mathrm{H}_{2} \mathrm{O}_{2}$ than most of the eukaryotic organisms.

However, what is the impact of $\mathrm{H}_{2} \mathrm{O}_{2}$ addition on the prokaryotic microbial communities in lakes? Several papers report on laboratory experiments investigating effects of $\mathrm{H}_{2} \mathrm{O}_{2}$ on specific groups of microorganisms, e.g., bacterial pathogens [46-48], root nodule bacteria $[49,50]$ and different members of the human microbiome [51,52]. The effect of $\mathrm{H}_{2} \mathrm{O}_{2}$ on the activity and composition of natural microbial communities has been investigated in small-scale incubations with eutrophic lake water or soils $[26,42,53,54]$. Santos et al. [42] recently described mesocosm experiments in which $\mathrm{H}_{2} \mathrm{O}_{2}$ addition led to increased abundances of Firmicutes and Proteobacteria and decreased abundances of Actinobacteria, Verrucomicrobia, Planctomycetes and Chloroflexi. Yet, the impact of large-scale $\mathrm{H}_{2} \mathrm{O}_{2}$ treatments on the entire microbial community of lakes has, to our knowledge, not been investigated thus far. Bacteria perform important ecological functions in freshwater environments, such as the decomposition of dead organic matter and the recycling of nutrients like carbon, nitrogen and sulfur [55,56]. From a lake management perspective, it is therefore of key interest to gain a better understanding of the potential impact of $\mathrm{H}_{2} \mathrm{O}_{2}$ treatments on the microbial communities of lakes.

This study sought to fill this gap by monitoring changes in microbial diversity and community composition using $16 \mathrm{~S}$ rRNA gene amplicon sequencing during two $\mathrm{H}_{2} \mathrm{O}_{2}$ treatments of an entire lake, one in June and the other in August (Figure 1A,B). Lake treatments represent "real-life" scenarios in which microbial communities are not only affected by the treatment, but may also respond to many other factors. Without adequate controls, it may be difficult to discern to what extent the observed changes in the microbial community composition are caused by the $\mathrm{H}_{2} \mathrm{O}_{2}$ treatment, by natural variability of the community or by concomitant changes of other environmental drivers (e.g., changing weather conditions). Therefore, both lake treatments were accompanied by replicated in situ lake incubations with two different $\mathrm{H}_{2} \mathrm{O}_{2}$ concentrations and a control (without $\mathrm{H}_{2} \mathrm{O}_{2}$ addition). The results of our study give insight in the resistance and resilience of the microbial community after lake treatments with $\mathrm{H}_{2} \mathrm{O}_{2}$, the taxa that suffer or benefit from the treatment and the extent to which $\mathrm{H}_{2} \mathrm{O}_{2}$ impacts the functioning of microbial communities. 


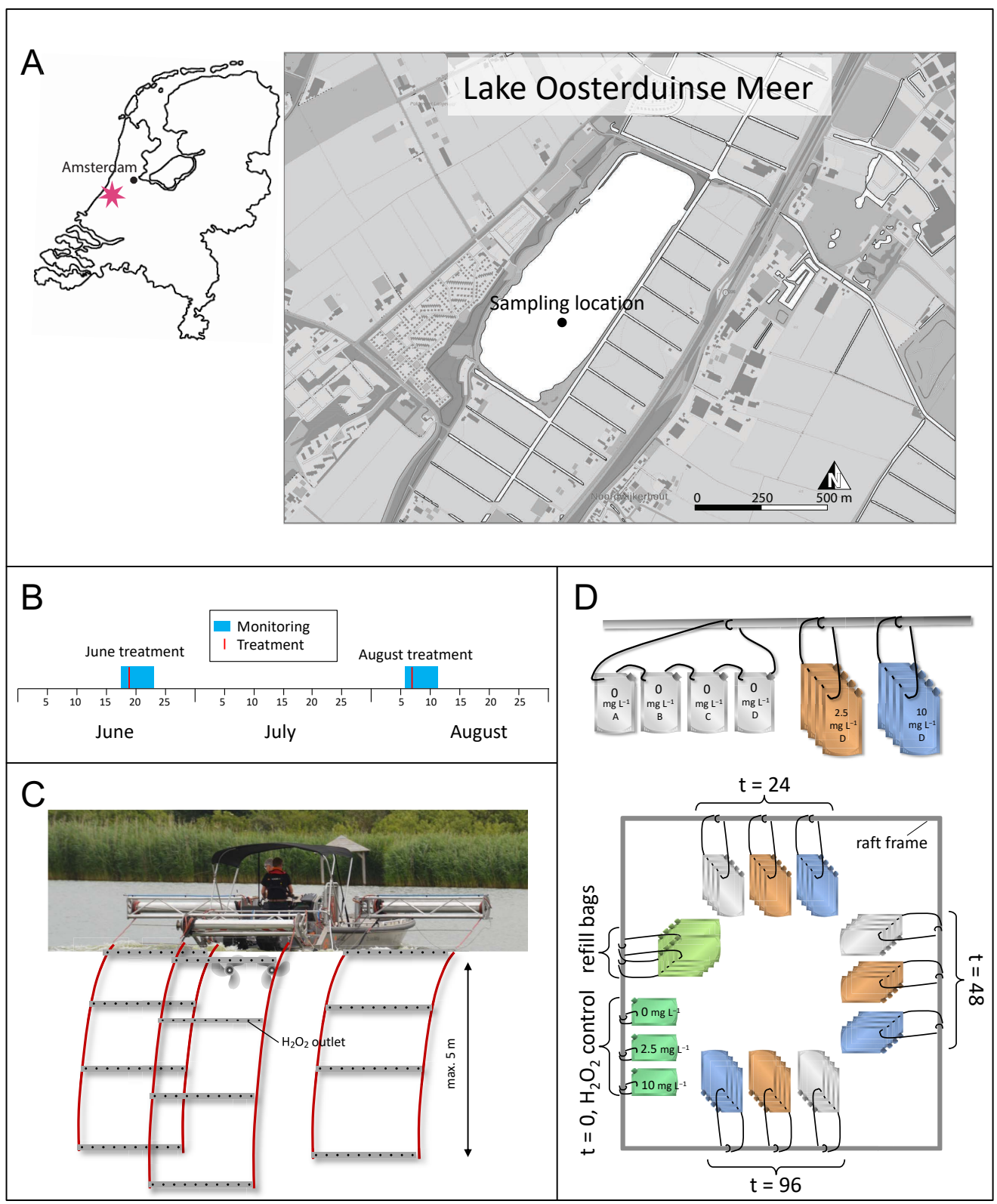

Figure 1. Location of the lake and experimental design. (A) The location of lake Oosterduinse Meer in The Netherlands and the sampling location in the lake. In June and August (B), $\mathrm{H}_{2} \mathrm{O}_{2}$ was carefully added to the top $5 \mathrm{~m}$ of the lake with the help of a specialized boat (C). Both lake treatments were accompanied by incubation experiments (D). The incubation bags were attached to a raft which was anchored at the sampling location in the lake. All the incubation bags were filled with surface lake water at $\mathrm{t}=-24 \mathrm{~h}$ and attached to the raft in groups of four replicate incubation bags per treatment condition (control, 2.5 and $\left.10 \mathrm{mg} \mathrm{L}^{-1} \mathrm{H}_{2} \mathrm{O}_{2}\right)$ and sampling time point $(\mathrm{t}=24 \mathrm{~h}$, $\mathrm{t}=48 \mathrm{~h}$ and $\mathrm{t}=96 \mathrm{~h}$ ). At the same time as the lake was treated with $\mathrm{H}_{2} \mathrm{O}_{2}$, the incubation bags of all the treatment conditions and sampling time points received $0 \mathrm{mg} \mathrm{L}^{-1} \mathrm{H}_{2} \mathrm{O}_{2}$ (Milli-Q) in the control incubations (gray) and $2.5 \mathrm{mg} \mathrm{L}^{-1} \mathrm{H}_{2} \mathrm{O}_{2}$ (orange) and $10 \mathrm{mg} \mathrm{L}^{-1} \mathrm{H}_{2} \mathrm{O}_{2}$ (blue) in the other experimental treatments. The three incubation bags at $\mathrm{t}=0 \mathrm{~h}$ (dark green) were treated with either 0 , 2.5 or $10 \mathrm{mg} \mathrm{L}^{-1} \mathrm{H}_{2} \mathrm{O}_{2}$ and immediately brought to shore and sampled $10 \mathrm{~min}$ after the treatment for $\mathrm{H}_{2} \mathrm{O}_{2}$ concentration determination as well as phytoplankton analysis. At each consecutive time point, the corresponding incubation bags of the three treatments (gray, orange and blue) were taken out of the water and brought to shore for analysis. Each mesocosm bag served as a biological replicate and was sampled only once. 


\section{Materials and Methods}

\subsection{Lake, $\mathrm{H}_{2} \mathrm{O}_{2}$ Treatment and Sampling Information}

Lake Oosterduinse Meer is located in a rural area close to the Dutch coast $\left(52^{\circ} 16^{\prime} 55^{\prime \prime} \mathrm{N}\right.$, $4^{\circ} 30^{\prime} 28^{\prime \prime}$ E) (Figure 1A). It covers 30 ha, has an average depth of $7 \mathrm{~m}$ (maximum depth of $13 \mathrm{~m}$ ) and is stratified during summer months. The lake is connected with the surrounding flower fields with a canal system. Consequently, the lake water is hypertrophic and especially rich in phosphorus, making it an excellent environment for cyanobacterial blooms.

In 2018, lake Oosterduinse Meer was treated twice with $\mathrm{H}_{2} \mathrm{O}_{2}$; the first treatment took place on 19 June, the second treatment-on 7 August (Figure 1B). During each treatment, $\mathrm{H}_{2} \mathrm{O}_{2}$ was applied to the top $5 \mathrm{~m}$ of the entire lake using a specialized boat (Figure 1C), carefully adding $4.2 \mathrm{~mL}$ of a $598 \mathrm{~g} \mathrm{~L}^{-1} \mathrm{H}_{2} \mathrm{O}_{2}\left(50 \% \mathrm{H}_{2} \mathrm{O}_{2}(w / w)\right)$ stock per $1 \mathrm{~m}^{3}$ of the lake water to treat the lake with a target concentration of $\sim 2.5 \mathrm{mg} \mathrm{L}^{-1} \mathrm{H}_{2} \mathrm{O}_{2}$. During the June treatment, the boat first treated the shallower waters along the shore of the lake, then went to the lake center, treating the sampling location by spiraling three times around it, before covering the rest of the lake from south to north with 75 diagonal lanes (Figure S1A). The average distance between the lanes was $13.3 \mathrm{~m}$ and the net treatment time was $7.3 \mathrm{~h}$. During the August treatment, the boat navigated the lake from south to north with 91 diagonal lanes, while the shallower parts along the shore were treated in between (Figure 2). The average distance between the lanes was $10.9 \mathrm{~m}$ and the net treatment time was $9.2 \mathrm{~h}$.
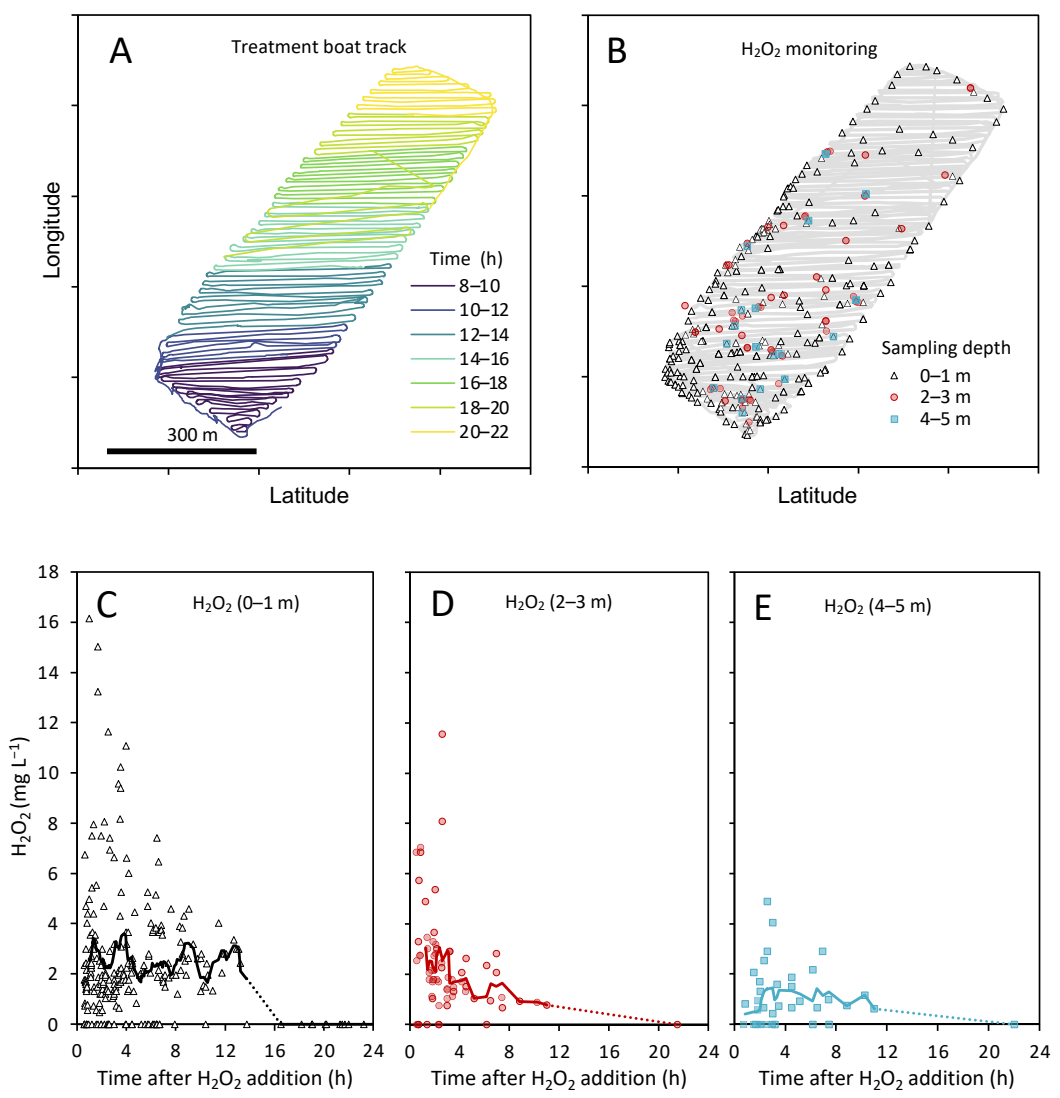

Figure 2. $\mathrm{H}_{2} \mathrm{O}_{2}$ treatment of the lake. The graph shows (A) the boat track during the treatment in August, (B) the sampling locations and the sampling depth where $\mathrm{H}_{2} \mathrm{O}_{2}$ concentrations were monitored during the treatment. (C-E) $\mathrm{H}_{2} \mathrm{O}_{2}$ concentrations measured at different time points after the treatment boat had passed the sampling locations, (C) at 0-1-m depth, (D) at 2-3-m depth and (E) at the 4-5-m depth. Colors in panel (A) indicate the time of day during which a certain section of the lake was treated; different symbols in panel (B) indicate the sampling depth; lines in panels (C-E) are moving averages with a window size of $60 \mathrm{~min}$. 
During the treatments, continuous measurements of temperature, $\mathrm{O}_{2}$ saturation, $\mathrm{pH}$ and light intensity were collected using a water column (surface to the bottom) from the center of the lake using a Hydrolab Datasonde 5 (OTT Messtechnik GmbH and Co., Kempten, Germany). Weather data from the weather station Schiphol located $\sim 20 \mathrm{~km}$ east of the lake were provided by the Royal Netherlands Meteorological Institute (KNMI) (www.knmi.nl; accessed on 10 January 2020).

Samples for DNA extraction, phytoplankton identification and quantification, analyses of nutrient concentrations and bacterial enumeration were taken from the $0-\mathrm{m}$ and 5-m depth at the sampling location in the middle of the lake. The samples from the 5-m depth were pumped up with a 1.4-bar water pump, type 088 (Barwig Wasserversorgung, Bad Karlshafen, Germany), connected to a 5-m-long tube. One day before the treatment $(t=-24 h)$, seven biological replicates were sampled from the $0-m$ depth, six biological replicates-from the 5-m depth. For all the other time points, at $0 \mathrm{~h}$ (just before the treatment, only for phytoplankton and nutrient analysis), $5 \mathrm{~h}, 24 \mathrm{~h}, 48 \mathrm{~h}$ and $96 \mathrm{~h}$ after the treatment, four biological replicates were taken from both depths. All the samples were collected in individual 5-L transparent plastic bags (DaklaPack, Lelystad, The Netherlands) and immediately processed on the shore.

For DNA extraction, a 1-L subsample was filtered instantly through a 5- $\mu$ m polycarbonate Cyclopore filter (Whatman $\mathrm{GmbH}$, Dassel, Germany) on a Nalgene ${ }^{\mathrm{TM}}$ filtration unit (ThermoScientific, Waltham, MA, USA) to remove most filamentous cyanobacteria, bigger eukaryotic organisms and particles. The filtrate containing planktonic bacteria that were not attached to bigger particles was collected and filtered again over a $0.2-\mu \mathrm{m}$ polycarbonate Cyclopore filter (Whatman $\mathrm{GmbH}$, Dassel, Germany). This filter was then carefully folded, placed into a $1.5-\mathrm{mL}$ screw cap tube and immediately snap frozen in a CX100 dry shipper (Taylor-Wharton/Worthington Industries, Columbus, OH, USA) at $-190{ }^{\circ} \mathrm{C}$ and later stored at $-80^{\circ} \mathrm{C}$ until analysis. Only $0.2-\mu \mathrm{m}$ polycarbonate Cyclopore filters were used for DNA extraction.

For phytoplankton analysis, 30-mL subsamples were taken from three of the biological replicates, fixed with $600 \mu \mathrm{L}$ acidic Lugol's iodine and immediately stored at $4{ }^{\circ} \mathrm{C}$ until further analysis.

For bacterial enumeration using flow cytometry, a 1.5-mL subsample was taken from each replicate, fixed with glutaraldehyde $(0.5 \%(v / v)$ final concentration prepared from a $25 \%(v / v)$ EM grade stock solution; VWR, Amsterdam, The Netherlands) at $4{ }^{\circ} \mathrm{C}$ for $15 \mathrm{~min}$, after which it was snap frozen and later stored at $-80{ }^{\circ} \mathrm{C}$ until analysis.

For the quantification of dissolved inorganic nutrients, 55-mL subsamples from each biological replicate were filtered over GF/C filters on a Millipore 1225 Sampling Manifold (Merck KGaA, Darmstadt, Germany). Subsequently, $15 \mathrm{~mL}$ of each filtrate were frozen and stored at $-20^{\circ} \mathrm{C}$ for nutrient analysis.

\subsection{Incubation Experiments}

Each lake treatment was accompanied by in situ incubation experiments with two $\mathrm{H}_{2} \mathrm{O}_{2}$ concentrations and a control. In contrast to an entire lake treatment aimed to provide valuable insight to a real-life scenario, these small-scale lake incubations allowed replication of different $\mathrm{H}_{2} \mathrm{O}_{2}$ treatments including controls without $\mathrm{H}_{2} \mathrm{O}_{2}$, which enables a more controlled (but less "realistic") study of the effect of $\mathrm{H}_{2} \mathrm{O}_{2}$ on microbial communities.

One day before a lake treatment $(\mathrm{t}=-24 \mathrm{~h}), 47$ transparent 5 - $\mathrm{L}$ food-grade plastic bags (DaklaPack, Lelystad, The Netherlands) were filled with lake water from $0 \mathrm{~m}$. These incubation bags were divided into nine groups of four bags each (to be sampled at $t=24$, $t=48$ and $t=96 \mathrm{~h})$, one group of three bags $(t=0 \mathrm{~h})$ and one group of eight "refill bags" (Figure 1D). All the incubation bags were attached to a raft at the sampling location at the lake center. A weight was attached to each group of bags, holding them submerged below the water at a constant depth of $1 \mathrm{~m}$.

On the treatment day, at the time that the treatment boat passed the sampling location, 12 incubation bags received $10 \mathrm{~mL}$ of Milli-Q water to serve as controls $\left(0 \mathrm{mg} \mathrm{L}-1 \mathrm{H}_{2} \mathrm{O}_{2}\right)$, 
12 incubation bags received $10 \mathrm{~mL}$ of a diluted $\mathrm{H}_{2} \mathrm{O}_{2}$ stock solution at a final concentration of $2.5 \mathrm{mg} \mathrm{L}^{-1} \mathrm{H}_{2} \mathrm{O}_{2}$ and another 12 incubation bags received $10 \mathrm{~mL}$ of an $\mathrm{H}_{2} \mathrm{O}_{2}$ stock solution at a final concentration of $10 \mathrm{mg} \mathrm{L}^{-1} \mathrm{H}_{2} \mathrm{O}_{2}$ (Figure 1D). After each addition of $\mathrm{H}_{2} \mathrm{O}_{2}$, water of the eight "refill bags" was used to completely fill up all the treated incubation bags to their total volume so that no air remained inside. At last, the three incubation bags of the $t=0$ group were treated with Milli-Q water, 2.5 and $10 \mathrm{mg} \mathrm{L}^{-1}$ $\mathrm{H}_{2} \mathrm{O}_{2}$, respectively, directly brought to the shore and sampled $10 \mathrm{~min}$ later. From each of these three incubation bags $(t=0)$, three individual subsamples were taken to measure the added $\mathrm{H}_{2} \mathrm{O}_{2}$ as well as to monitor phytoplankton and quantify dissolved inorganic nutrient concentrations. At each consecutive time point $(t=24,48$ and $96 \mathrm{~h})$, four incubation bags from each of the three treatments $\left(0 \mathrm{mg} \mathrm{L}^{-1}, 2.5 \mathrm{mg} \mathrm{L}^{-1}\right.$ and $\left.10 \mathrm{mg} \mathrm{L}^{-1} \mathrm{H}_{2} \mathrm{O}_{2}\right)$ were removed from the raft and brought to the shore for immediate analysis (Figure 1D). All four incubation bags from each of the three experimental treatments were sampled for DNA extraction, nutrient analysis and bacterial abundances, while three incubation bags from each experimental treatment were sampled for phytoplankton analysis. The samples were handled and stored in the same way as described above for the field sampling.

\section{3. $\mathrm{H}_{2} \mathrm{O}_{2}$ Measurements}

The $\mathrm{H}_{2} \mathrm{O}_{2}$ concentration was frequently measured at several locations across the lake throughout the treatment day using peroxide quantification strips (sensitivity range: 0.5-25 mg L ${ }^{-1}$, Quantofix ${ }^{\circledR}$, Macherey-Nagel GmbH and Co., KG; Dueren, Germany) and a mobile strip reader (Quantofix ${ }^{\circledR}$, Macherey-Nagel GmbH and Co., KG). Only those measurements that were taken at least $30 \mathrm{~min}$ after the boat had treated the monitored location were considered. Time and GPS coordinates of the boat and each monitored location were used to calculate the time difference between the time of sampling and the time the boat passed nearest (and latest) by the sampling location. The $\mathrm{H}_{2} \mathrm{O}_{2}$ concentrations from the raft location were additionally measured regularly with a more sensitive colorimetric assay ( $p$ nitrophenylboronic acid) according to Lu et al. [57] and Piel et al. [38]. These measurements were also used to calibrate the strip measurements. In short, 55-mL samples from each of the sampling depths were filtered through GF/C glass fiber filters (Whatman GmbH, Dassel, Germany), and $100 \mu \mathrm{L}$ of the filtrate were immediately mixed with $100 \mu \mathrm{L}$ of $2 \mathrm{mM}$ p-nitrophenylboronic acid reagent (Merck KGaA, Darmstadt, Germany) in a 96-well plate. After incubating the assay for 30-45 min in almost complete darkness, the absorption of $p$-nitrophenolate was measured at its absorption peak (405 nm) using a plate reader (Multiscan FC type 357, ThermoScientific, Waltham, MA, USA). Each sample was analyzed in triplicates with each replicate consisting of three technical replicates. A $33 \%(w / w)$ stock solution (VWR, Amsterdam, The Netherlands) was used to make a calibration curve (in the range of $0.01-10 \mathrm{mg} \mathrm{L}^{-1} \mathrm{H}_{2} \mathrm{O}_{2}$ ) that was included on each 96-well plate. Since this assay is extremely sensitive to sunlight and cannot be easily implemented in the field, it was necessary to perform all the steps of this analysis indoors in the dark. The measurements of the strips and the colorimetric assay showed a close correlation $\left(R^{2}=0.93\right)$.

\subsection{Quantification of Dissolved Inorganic Nutrients}

The filtrates for nutrient analysis (see details above) were thawed and subsequently filtered over $0.2-\mu \mathrm{m}$ pore size $25-\mathrm{mm}$ Whatman polycarbonate membrane filters (GE Healthcare, Buckinghamshire, UK). Concentrations of dissolved ammonia, nitrates, nitrites and phosphates were measured using a San++ Automated Wet Chemistry Analyzer (Skalar Analytical B.V., Breda, The Netherlands) at a detection limit of $0.10 \mu \mathrm{mol} \mathrm{L}^{-1}, 0.02 \mu \mathrm{mol}$ $\mathrm{L}^{-1}, 0.03 \mu \mathrm{mol} \mathrm{L}^{-1}$ and $0.03 \mu \mathrm{mol} \mathrm{L}-1$, respectively.

\subsection{Microscopic Analysis of Phytoplankton}

Phytoplankton in a 1-mL subsample of the sample fixed with Lugol's iodine was identified to the genus or species level using an inverted microscope (Zeiss IM35, Oberkochen, Germany) and quantified following the Utermöhl method [58] using a counting chamber. 
Biovolumes of the phytoplankton were calculated from cell numbers, measured cell sizes and cellular geometry according to [59].

\subsection{Flow Cytometric Analysis of Prokaryotes}

Single-celled prokaryotes (bacteria, archaea) were quantified using a Becton Dickinson FACSCalibur flow cytometer (BD Biosciences, San Jose, CA, USA) according to the protocol suggested by Marie et al. [60]. The thawed samples were diluted in $0.2 \mu \mathrm{m}$ filtered (FP 30/0.2 CA-S Whatman, Dasser, Germany) 10:1 Tris-EDTA buffer (pH 8), stained with the nucleic acid-specific green fluorescent dye SYBR Green I at a final concentration of $1 \times 10^{-4}$ commercial stock (Invitrogen Molecular Probes, Eugene, OR, USA) for $15 \mathrm{~min}$ in the dark at room temperature, followed by flow cytometric analysis with the trigger set on green fluorescence. The microbial cells were discriminated by plotting green fluorescence against the side scatter using Flowing Software (version 2.5.1; www.flowingsoftware.com; accessed on 7 January 2020).

\subsection{DNA Extraction}

DNA was extracted using a DNeasy ${ }^{\circledR}$ PowerSoil ${ }^{\circledR}$ extraction kit (Qiagen, Hilde, Germany) according to the manufacturer's guidelines. The extracted DNA concentrations were quantified using a Qubit 2.0 fluorometer (Invitrogen, Carlsbad, CA, USA) and diluted to $\sim 25 \mathrm{ng} \mu \mathrm{L}^{-1}$ before drying in a CentriVap Concentrator (Labconco, Kansas City, MO, USA). Dried DNA was then shipped at room temperature for sequencing.

\section{8. $16 \mathrm{~S}$ rRNA Gene Amplicon Sequencing and Data Analysis}

First, the lake samples were used to compare the suitability of different primer pairs for $16 \mathrm{~S}$ rRNA gene amplicon sequencing. With general primer pairs covering the V3$\mathrm{V} 5$ region (i.e., 515F-Y/926R), however, cyanobacteria comprised more than $80 \%$ of the reads per sample, whereas the number of reads of most other bacteria in the microbial community was low. Since cyanobacteria were already quantified by microscopy, we therefore decided to use the primer pair 799F (5'-AACMGGATTAGATACCCKG-3') and 1193R (5'-ACGTCATCCCCACCTTCC $3^{\prime}$ ) [61,62], which targets the V5-V7 region of the $16 \mathrm{~S}$ rRNA gene but specifically avoids amplification of chloroplast DNA and cyanobacteria. The main advantage of this approach is that high resolution of the microbial community can be achieved because the data are not cluttered by large numbers of cyanobacterial reads. A 30-cycle PCR was performed by MR DNA (Shallowater, TX, USA) with added barcodes to the forward primer using a HotStarTaq Plus Master Mix Kit (Qiagen, Germantown, MD, USA) under the following conditions: $94{ }^{\circ} \mathrm{C}$ for $3 \mathrm{~min}$ followed by 30 cycles of $94{ }^{\circ} \mathrm{C}$ for $30 \mathrm{~s}, 53{ }^{\circ} \mathrm{C}$ for $40 \mathrm{~s}$ and $72{ }^{\circ} \mathrm{C}$ for $1 \mathrm{~min}$, with the final elongation step at $72{ }^{\circ} \mathrm{C}$ for $5 \mathrm{~min}$. PCR products were checked on a $2 \%$ agarose gel to determine amplification success. The samples were then pooled in five equal pools each with equal proportions of molecular weight and DNA concentrations and purified with calibrated AMPure XP beads. All the five pools were then used to prepare the Illumina DNA libraries. Each pool was sequenced on a separate run on an Illumina MiSeq at MR DNA (Shallowater, TX, USA) according to the manufacturer's guidelines. In addition, three samples were added to each of the five individual runs to verify that the run-to-run variation was minimal (Figure S2). Furthermore, four replicates of the so-called "mock community," a mixture of 10 well-characterized bacterial strains in equal amounts (MSA-1000 ${ }^{\mathrm{TM}}$, ATCC ${ }^{\circledR}$, Manassas, VA, USA), were added to confirm classification accuracy and check for possible primer bias. Analysis of the mock community results with the evaluate-composition command of the q2-quality control plugin of QIIME2 version 2019.4 [63] indicated that at the genus level, the taxon detection rate was $100 \%$ and that the relative abundances of the observed taxa were close to the expected levels.

The sequence data for this study were deposited in the European Nucleotide Archive (ENA) at the EMBL-EBI under accession number PRJEB44985 (https:/ / www.ebi.ac.uk/ena/ 
browser/view/PRJEB44985; accessed on 6 April 2021) and the corresponding metadata are summarized in Table S1.

Raw sequences were transformed with the FASTQ processer of MR DNA (Shallowater, TX, USA) before analysis with QIIME2 (versions 2019.4 and 2019.10) [63]. The sequences were demultiplexed $[64,65]$, then joined and quality-trimmed during DADA2 denoising [66] to a quality score of at least 20 and with an overlap of at least 20 nucleotides. Feature tables of amplicon sequencing variants (ASVs) and representative sequences (repseqs) tables of all the five runs were subsequently merged using the q2-feature-table plugin. Taxonomic classification was performed with the q2-feature-classifier plugin [67] by first training the machine-learning classifier on the sequences generated by the primer (799F/1193R) using the fit-classifier-naive-bayes command [68]. The subsequent classification was performed using the classify-sklearn command and 99\% SILVA database version 132 as the reference $[69,70]$. A phylogenetic tree (SEPP) was generated using the q2-fragment-insertion plugin [71] to allow for phylogenetic diversity analyses such as UniFrac distances and Faith's phylogenetic diversity (PD).

Alpha diversity analysis was performed on rarefied but unfiltered feature tables. To allow for comparisons of alpha diversity between all the treatments and conditions of this study, all the samples were rarefied to the same sampling depth of 22,554 using the rarefy command in the feature-table plugin [72]. Chao-1 index and Faith's PD were generated using the q2-diversity plugin. Pairwise Kruskal-Wallis tests were used to compare the indices of different time points.

Beta diversity was quantified as Bray-Curtis dissimilarity and as UniFrac distances. Mild low-frequency filtration was applied to all the samples to remove rare or potentially faulty features (i.e., features with less than four reads were removed). With the core-metrics command of the q2-diversity plugin, all the lake samples were rarefied to a minimal sampling depth of 22,554, all the samples of the lake incubations (including the $\mathrm{t}=-24$ samples) - to a minimal sampling depth of 23,593 before calculating Bray-Curtis dissimilarity and unweighted UniFrac distance matrices [73-78]. Principal coordinates analysis (PCOA) plots visualizing the beta diversity matrices were generated in QIIME2 (versions 2019.4 and 2019.10). Subsequently, a pairwise PERMANOVA was used to calculate significant differences between clusters in the same PCoA plot [79].

Relative abundance plots were generated for bacterial abundances in the lake (at the $0-\mathrm{m}$ and 5-m depth) and in the incubation experiments for both the June and August treatments using the 50 most abundant taxa at the order level (covering more than $99 \%$ of the relative abundances) and the 25 most abundant taxa at the genus level. The graphs were generated with the original unrarefied feature tables as rarefaction is not required with centered log ratio (clr) transformation [80]. Since clr transformation is sensitive to sparse data with many zero values, a prior filtration step was included to filter out all the rare features $<25$ reads and presence in less than four samples. This filtration step resulted in a $58.38 \pm 2.27 \%$ decrease in the number of features, but only in a $0.55 \pm 0.15 \%$ decrease in the total read counts. Despite the strong decrease in features, the Mantel test between unfiltered and filtered dissimilarity/distance matrixes confirmed significant correlation. Sequence counts were clr-transformed with the aldex.clr function of the package ALDEx2 (version 1.18.0) [81,82] in $\mathrm{R}$ (version 3.6.2) and the median of 128 Monte Carlo Dirichlet instances was extracted. The dot plot was generated using the scales package (version 1.1.0) in $\mathrm{R}$ (version 3.6.2) and a slightly adjusted DotPlot function according to Guevara Campoverde et al. [83].

Differential abundance between the control incubations $\left(0 \mathrm{mg} \mathrm{L}^{-1} \mathrm{H}_{2} \mathrm{O}_{2}\right)$ and the treated incubations $\left(2.5 \mathrm{mg} \mathrm{L}^{-1}\right.$ and $\left.10 \mathrm{mg} \mathrm{L}^{-1} \mathrm{H}_{2} \mathrm{O}_{2}\right) 24 \mathrm{~h}$ and $96 \mathrm{~h}$ after addition of $\mathrm{H}_{2} \mathrm{O}_{2}$ was calculated using filtered clr-transformed feature tables that were collapsed at the order and genus level and the aldex.ttest and aldex.effect functions [81,82,84]. The effect size as calculated in ALDEx2 $(0.7 \times$ Cohen's $d)$ is shown in a heat map for each comparison with a significant Welch's $t$-test $(p<0.05$ after correction for multiple hypothesis testing according to Benjamini and Hochberg [85]). Heat maps of the effect size of differentially 
relative abundance orders was generated using the gplots (version 3.0.3) package in $\mathrm{R}$ (version 3.6.2).

To predict ecological functions of bacteria during the treatments, the samples were analyzed with PICRUSt2 [86] and Tax4Fun2 [87]. Techniques and databases for functional predictions are still in development, and PICRUSt2 and Tax4Fun2 follow different methods and make use of different reference databases. Therefore, we analyzed our data with both pipelines and compared their predictions to assess the robustness of the results. The predicted KEGG orthologs of both pipelines were corrected by the 16S gene copy number [86,87]. The selected KEGG orthologs classified as glycoside hydrolases according to the Carbohydrate Active Enzymes database ([88]; http:/ / www.cazy.org; accessed on 12 January 2020) as well as the orthologs involved in the anti-ROS activity or belonging to fundamental nutrient cycling pathways according to the KEGG database [89-91] were clustered and analyzed further. The PICRUSt2 predicted the KEGG orthologs were clrtransformed, and the differential relative abundances between the experimental treatments and the control of the lake incubations were calculated using ALDEx2 as mentioned above. The Tax4Fun2 prediction output of the KEGG orthologs is given as percentage values of relative abundances and could not be clr-transformed as the PICRUSt 2 data. The output values were therefore $\log _{2}$-transformed and the Wilcoxon test with $p$-values corrected for multiple hypothesis testing [85] was used to calculate the differential relative abundances of the KEGG orthologs between the experimental treatments and the control. Dot plots and heat maps indicating significant increases or decreases in the relative abundances were generated using the gplots (version 3.0.3) package in $\mathrm{R}$ (version 3.6.2).

\section{Results}

The results of the two $\mathrm{H}_{2} \mathrm{O}_{2}$ treatments of the lake were quite comparable. For conciseness, we present only the August treatment in detail here, and highlight important differences with the June treatment (Supplementary Materials) at the end of Section 3. From now on, we refer to the August treatment as "the treatment" unless specified otherwise.

\section{1. $\mathrm{H}_{2} \mathrm{O}_{2}$ Concentrations during the Treatment}

The lake treatment aimed to obtain the target $\mathrm{H}_{2} \mathrm{O}_{2}$ concentration of $2.5 \mathrm{mg} \mathrm{L}^{-1}$ across the top $5 \mathrm{~m}$ of the entire lake by careful injection of $\mathrm{H}_{2} \mathrm{O}_{2}$ from a specially designed boat (Figure 1C). Measurements in the surface water (0-1-m depth) at various locations across the entire lake (Figure 2B) showed relatively stable average concentrations between 2 and $3 \mathrm{mg} \mathrm{L}^{-1} \mathrm{H}_{2} \mathrm{O}_{2}$ for up to $\sim 13 \mathrm{~h}$ after the treatment boat had passed (Figure 2C). Deeper in the lake (2-3- and 4-5-m depth), the average concentrations varied between 0.7 and $3 \mathrm{mg} \mathrm{L}^{-1} \mathrm{H}_{2} \mathrm{O}_{2}$ during this time period (Figure 2D,E). One day later (at $\mathrm{t}>20 \mathrm{~h}$ ), the added $\mathrm{H}_{2} \mathrm{O}_{2}$ was degraded to $<0.01 \mathrm{mg} \mathrm{L}^{-1}$.

In the incubation experiments, the first $\mathrm{H}_{2} \mathrm{O}_{2}$ measurement was about $10 \mathrm{~min}$ after the $\mathrm{H}_{2} \mathrm{O}_{2}$ addition, displaying a rapid decline to $1.6 \pm 0.1 \mathrm{mg} \mathrm{L}^{-1} \mathrm{H}_{2} \mathrm{O}_{2}$ in the $2.5 \mathrm{mg} \mathrm{L}^{-1}$ treatment and to $8.5 \pm 0.6 \mathrm{mg} \mathrm{L}^{-1} \mathrm{H}_{2} \mathrm{O}_{2}$ in the $10 \mathrm{mg} \mathrm{L}^{-1}$ treatment. The added $\mathrm{H}_{2} \mathrm{O}_{2}$ was degraded to $<0.01 \mathrm{mg} \mathrm{L}^{-1}$ in all the incubation experiments after $24 \mathrm{~h}$.

\subsection{Environmental Data during the Treatment}

The treatment day was characterized by very warm weather (maximum air temperature of $33.7^{\circ} \mathrm{C}$ ) accompanied by vertical microstratification of the lake temperature and supersaturated oxygen concentrations in the surface layer of the lake (Figure S3, Table S2). The subsequent cooler weather resulted in a more homogeneous temperature distribution over the upper $4 \mathrm{~m}$ of the epilimnion on the day after the treatment followed by a further deepening of the thermocline to $\sim 6-\mathrm{m}$ depth during the next few days (Figure S3B). Dissolved oxygen in the surface layer declined in the days after the $\mathrm{H}_{2} \mathrm{O}_{2}$ treatment but penetrated deeper into the water column as the anoxic hypolimnion gradually moved from the 4-m depth prior to the treatment to $>6-\mathrm{m}$ depth at day 4 after the treatment (Figure S3D). The $\mathrm{pH}$ in the surface layer declined from 9.5 before the treatment to 8.7 in 
the days after the treatment (Figure S3F). The lake was very turbid prior to the treatment, with a euphotic depth (defined as the depth receiving 1\% of the surface irradiance) of $\sim 0.9 \mathrm{~m}$. Within $5 \mathrm{~h}$ after the start of the treatment, sunlight penetrated deeper into the water column, and after 4 days, the euphotic zone extended to $\sim 2.6-\mathrm{m}$ depth (Figure $\mathrm{S} 3 \mathrm{H}$ ).

The $\mathrm{NH}_{4}{ }^{+}$and $\mathrm{PO}_{4}{ }^{3-}$ concentrations increased after the $\mathrm{H}_{2} \mathrm{O}_{2}$ treatment of the entire lake, with a particularly pronounced increase of $\mathrm{NH}_{4}{ }^{+}$at the $0-\mathrm{m}$ depth (whereas the $\mathrm{NO}_{3}{ }^{-}$ and $\mathrm{NO}_{2}{ }^{-}$concentrations remained low; Figure S4). A similar strong increase of the $\mathrm{NH}_{4}{ }^{+}$ concentration was also found in the lake incubations treated with 2.5 and $10 \mathrm{mg} \mathrm{L}^{-1} \mathrm{H}_{2} \mathrm{O}_{2}$, whereas the $\mathrm{NO}_{3}{ }^{-}, \mathrm{NO}_{2}{ }^{-}$and $\mathrm{PO}_{4}{ }^{3-}$ concentrations in the lake incubations remained largely unaltered after the treatment (Figure $\mathrm{S} 4$ ).

\subsection{Effects of $\mathrm{H}_{2} \mathrm{O}_{2}$ on Phytoplankton}

Prior to the lake treatment, Planktothrix agardhii and Dolichospermum sp. Were the dominant cyanobacteria at the surface of the lake with biovolumes of $11.5 \pm 1.2 \mathrm{~mm}^{3} \mathrm{~L}^{-1}$ and $10.5 \pm 1.1 \mathrm{~mm}^{3} \mathrm{~L}^{-1}$, respectively (Figure $3 \mathrm{~A}$ ). The biovolumes of other cyanobacteria, including Microcystis and Aphanizomenon, were $<0.1 \mathrm{~mm}^{3} \mathrm{~L}^{-1}$. Eukaryotic phytoplankton (almost exclusively consisting of the dinoflagellate Ceratium spp.) were also highly abundant in the surface layer before the treatment with a total biovolume of $18.7 \pm 1.8 \mathrm{~mm}^{3} \mathrm{~L}^{-1}$. Cyanobacteria and eukaryotic phytoplankton were hardly present at the 5-m depth (Figure 3B). As soon as $5 \mathrm{~h}$ after the lake treatment, the biovolume of the surface-dwelling Dolichospermum sp. Was reduced by $95 \%$, and it completely disappeared in the subsequent days. The biovolume of P. agardhii declined steadily, but at a much lower rate than the biovolume of Dolichospermum sp. The biovolume of eukaryotic phytoplankton also decreased after the treatment before stabilizing between 48 and $96 \mathrm{~h}$ after the treatment (Figure 3A).
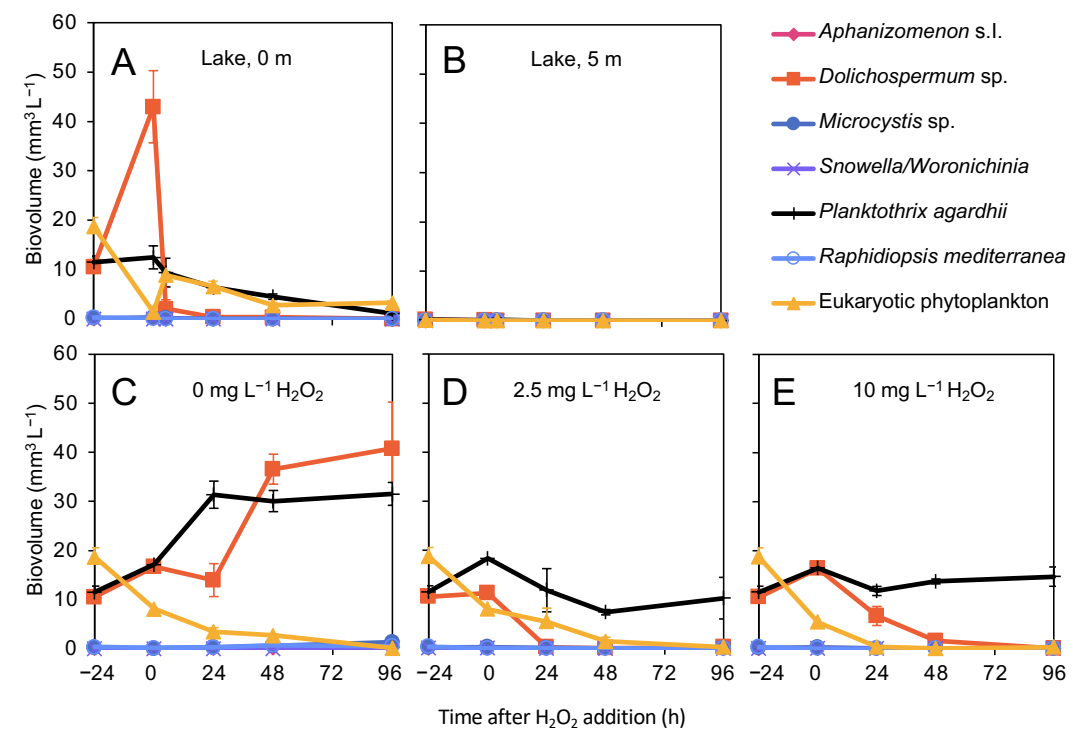

Figure 3. Phytoplankton composition during the $\mathrm{H}_{2} \mathrm{O}_{2}$ treatment in August. (A,B) Biovolume of the most abundant cyanobacterial taxa and of the total eukaryotic phytoplankton at (A) the 0-m and (B) 5-m depth during the $\mathrm{H}_{2} \mathrm{O}_{2}$ treatment of the lake in August. (C-E) Biovolumes in the incubation experiments treated with (C) $0 \mathrm{mg} \mathrm{L}^{-1}$, (D) $2.5 \mathrm{mg} \mathrm{L}^{-1}$ and $€ 10 \mathrm{mg} \mathrm{L}^{-1}$ of $\mathrm{H}_{2} \mathrm{O}_{2}$. The data show the mean $( \pm \mathrm{SD})$ of $n=$ three biological replicates per time point.

In the control of the incubation experiments (without $\mathrm{H}_{2} \mathrm{O}_{2}$ addition), the biovolume of the cyanobacteria strongly increased while the biovolume of eukaryotes (again, mostly Ceratium spp.) declined. In the $\mathrm{H}_{2} \mathrm{O}_{2}$-treated incubations, the cyanobacterium Dolichospermum sp. and the eukaryotic phytoplankton disappeared almost completely within 24 to $48 \mathrm{~h}$, whereas the biovolume of $P$. agardhii remained stable throughout the entire experiment (Figure 3C-E). 


\subsection{Bacterial Abundances}

In the surface layer $(0 \mathrm{~m})$ of the lake, bacterial abundances peaked $24 \mathrm{~h}$ after the addition of $\mathrm{H}_{2} \mathrm{O}_{2}$, after which they declined again. In contrast, at the 5-m depth, bacterial abundances remained stable for the first $48 \mathrm{~h}$, followed by a decline to values similar to those at $0 \mathrm{~m}$ (Figure $4 \mathrm{~A}$ ). In the control and the $2.5 \mathrm{mg} \mathrm{L}^{-1} \mathrm{H}_{2} \mathrm{O}_{2}$-treated incubations, bacterial abundances slowly increased towards the end of the experiment. In the $10 \mathrm{mg} \mathrm{L}^{-1}$ $\mathrm{H}_{2} \mathrm{O}_{2}$-treated incubations, bacterial numbers increased in the first $24 \mathrm{~h}$ before returning to the initial numbers (Figure 4B).

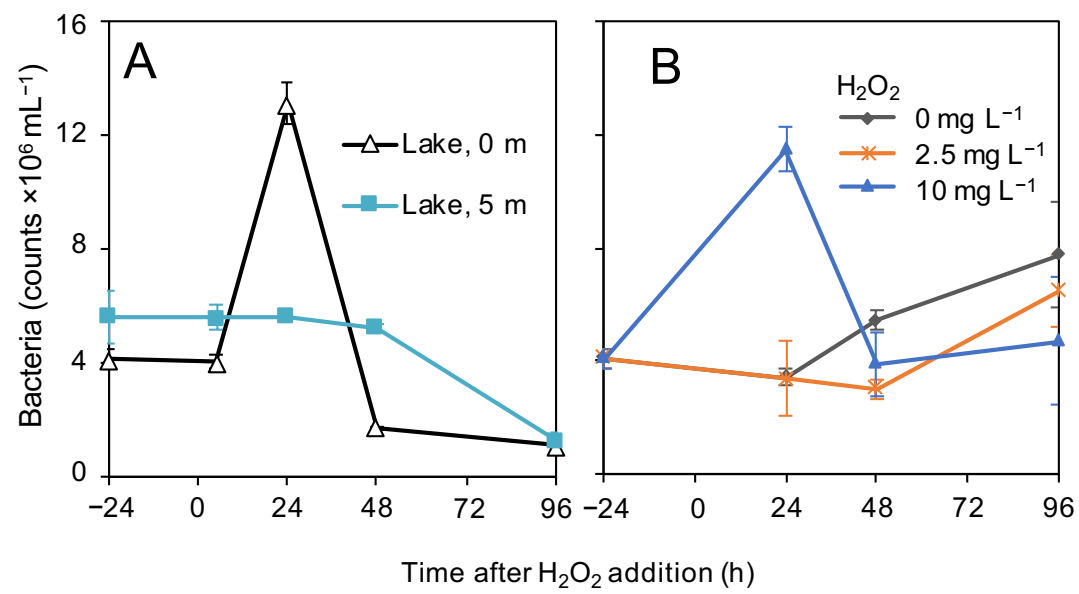

Figure 4. Total bacterial abundances during the $\mathrm{H}_{2} \mathrm{O}_{2}$ treatment in August. Total bacterial abundances as determined with flow cytometry during (A) the lake treatment and (B) the incubation experiments in August. The data show the mean $( \pm \mathrm{SD})$ based on $n=$ seven biological replicates for $\mathrm{t}=-24 \mathrm{~h}$ at $0 \mathrm{~m}(\mathbf{A}), n=$ six biological replicates for $\mathrm{t}=-24 \mathrm{~h}$ at $5 \mathrm{~m}(\mathbf{B})$ and $n=$ four biological replicates for all the other time points.

\subsection{Microbial Community Analysis}

\subsubsection{Microbial Community Composition in the Lake}

The microbial community composition showed clear differences between the oxygenrich surface layer and the oxygen-depleted waters at the 5-m depth already prior to the $\mathrm{H}_{2} \mathrm{O}_{2}$ treatment of the lake (Figure 5). Although the orders Frankiales and Betaproteobacteriales had high relative abundances at both depths, Flavobacteriales, for example, showed high relative abundances in the surface layer, whereas Bacteroidales, Sphingobacteriales, WCHB1-41 and Izimaplasmatales reached high relative abundances at the 5-m depth (Figure 5).

The bacterial taxa that showed a strong increase in the relative abundance after the $\mathrm{H}_{2} \mathrm{O}_{2}$ treatment in the surface layer of the lake included the orders Bacteroidales, Flavobacteriales, Bacillales, Alteromonadales, Methylococcales, Pseudomonadales, Izimaplasmatales and Chthoniobacterales (Figure 5A). In particular, the genera Rheinheimera (Alteromonadales) and Flavobacterium (Flavobacteriales) increased from $0.2 \%$ and $23 \%$ at $24 \mathrm{~h}$ before $\mathrm{H}_{2} \mathrm{O}_{2}$ addition to $44 \%$ and $45 \%$ of the microbial community at $24 \mathrm{~h}$ after $\mathrm{H}_{2} \mathrm{O}_{2}$ addition (Figure S5A; Table S3). Their relative abundances fell back again during the subsequent days, however, to $2 \%$ for Rheinheimera and $10 \%$ for Flavobacterium at $96 \mathrm{~h}$ after $\mathrm{H}_{2} \mathrm{O}_{2}$ addition. Conversely, the taxa that showed a decrease in the relative abundance after the $\mathrm{H}_{2} \mathrm{O}_{2}$ treatment included the orders Microtrichales, OPB56, Caedibacterales, unclassified Alphaproteobacteria, Myxococcales, Oligoflexales and Leptospirales (Figure 5A).

The relative abundances at the 5-m depth were somewhat more stable. The taxa that increased in the relative abundance at the 5-m depth after the $\mathrm{H}_{2} \mathrm{O}_{2}$ treatment included Flavobacteriales, uncultured Berkelbacteria, Rhodobacterales, Alteromonadales (again, especially Rheinheimera), Methylococcales, Pseudomonadales and Chthoniobacterales, while the taxa that decreased in the relative abundance included Babeliales and Phycisphaerales (Figure 5B; Figure S5B). 


\subsubsection{Microbial Community Composition in the Incubation Experiments}

The incubation experiments showed a strong initial increase in the relative abundance of Alteromonadales, and especially the genus Rheinheimera, in response to the $\mathrm{H}_{2} \mathrm{O}_{2}$ treatment (Figure 6; Figure S6). At $\mathrm{t}=24 \mathrm{~h}$, Rheinheimera increased to $73 \%$ and $62 \%$ of the microbial community in the incubations treated with 2.5 and $10 \mathrm{mg} \mathrm{L}^{-1} \mathrm{H}_{2} \mathrm{O}_{2}$, respectively, whereas it comprised only $12 \%$ of the microbial community in the control without $\mathrm{H}_{2} \mathrm{O}_{2}$ (Table S3). During the subsequent days, at $\mathrm{t}=96 \mathrm{~h}$ after $\mathrm{H}_{2} \mathrm{O}_{2}$ addition, the relative abundance of Rheinheimera declined again to $8 \%$ and $34 \%$ of the microbial community in the treatments with 2.5 and $10 \mathrm{mg} \mathrm{L}^{-1} \mathrm{H}_{2} \mathrm{O}_{2}$, respectively. The other taxa with a significantly higher relative abundance after the addition of $2.5 \mathrm{mg} \mathrm{L}^{-1} \mathrm{H}_{2} \mathrm{O}_{2}$ than in the control included the orders Frankiales, Rickettsiales and Cellvibrionales, while the taxa with a significantly lower relative abundance included Cytophagales, Flavobacteriales, Phycisphaerales, Pirellulales, Pedosphaerales and Verrucomicrobiales (Figure 6). The other taxa with a significantly higher relative abundance after the addition of $10 \mathrm{mg} \mathrm{L}^{-1} \mathrm{H}_{2} \mathrm{O}_{2}$ included Frankiales, unclassified Bacteroidia, Bacteroidales, Bacillales, Paracaedibacterales, Rhodobacterales, Rickettsiales, Aeromonadales, Betaproteobacteriales, Cellvibrionales and Pseudomonadales, while the taxa with a significantly lower relative abundance included Chitinophagales, Cytophagales, Babeliales, Phycisphaerales, Acetobacterales, uncultured Alphaproteobacteria, Oligoflexales, Chthoniobacterales, Pedosphaerales and Verrucomicrobiales (Figure 6).

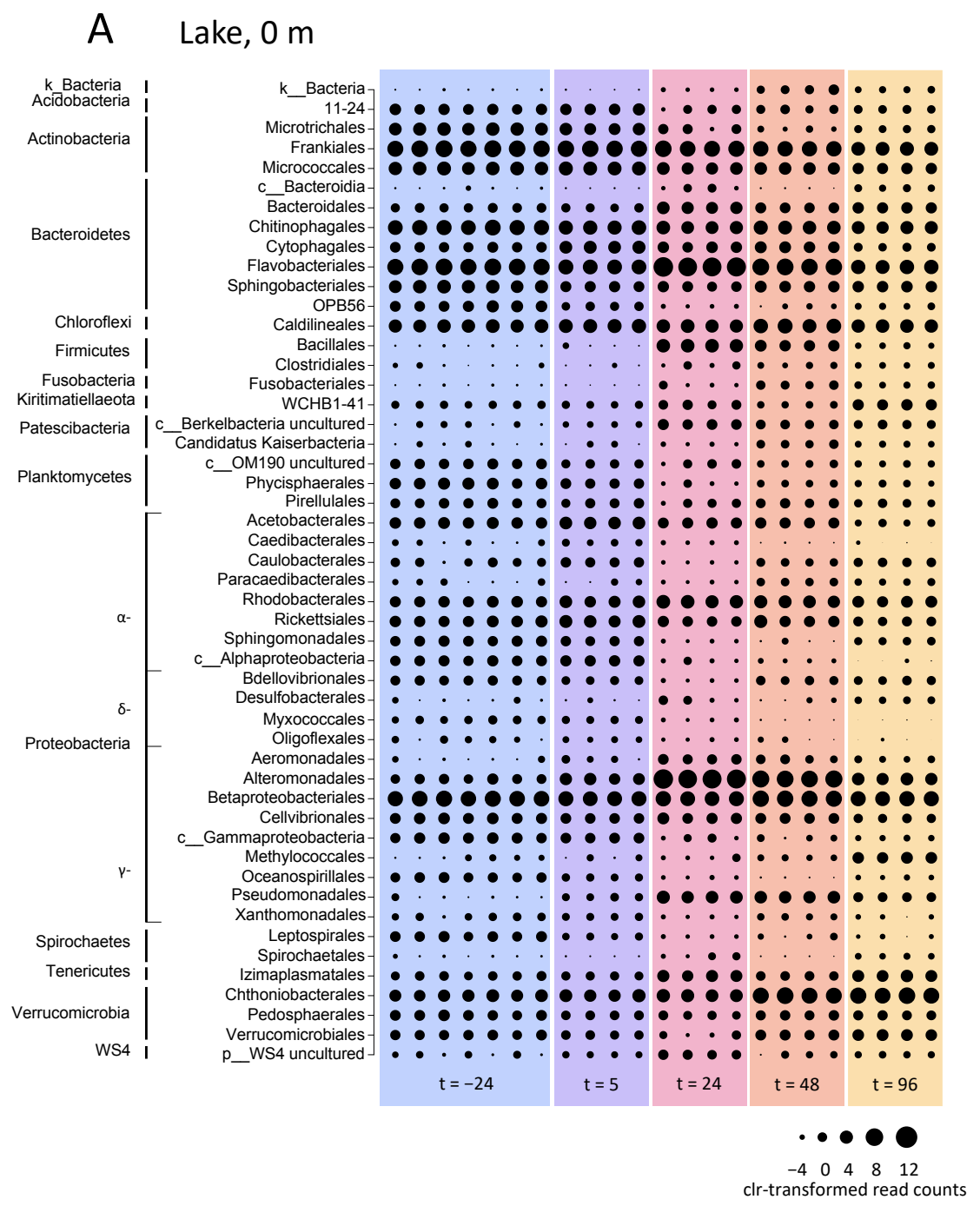

Figure 5. Cont. 


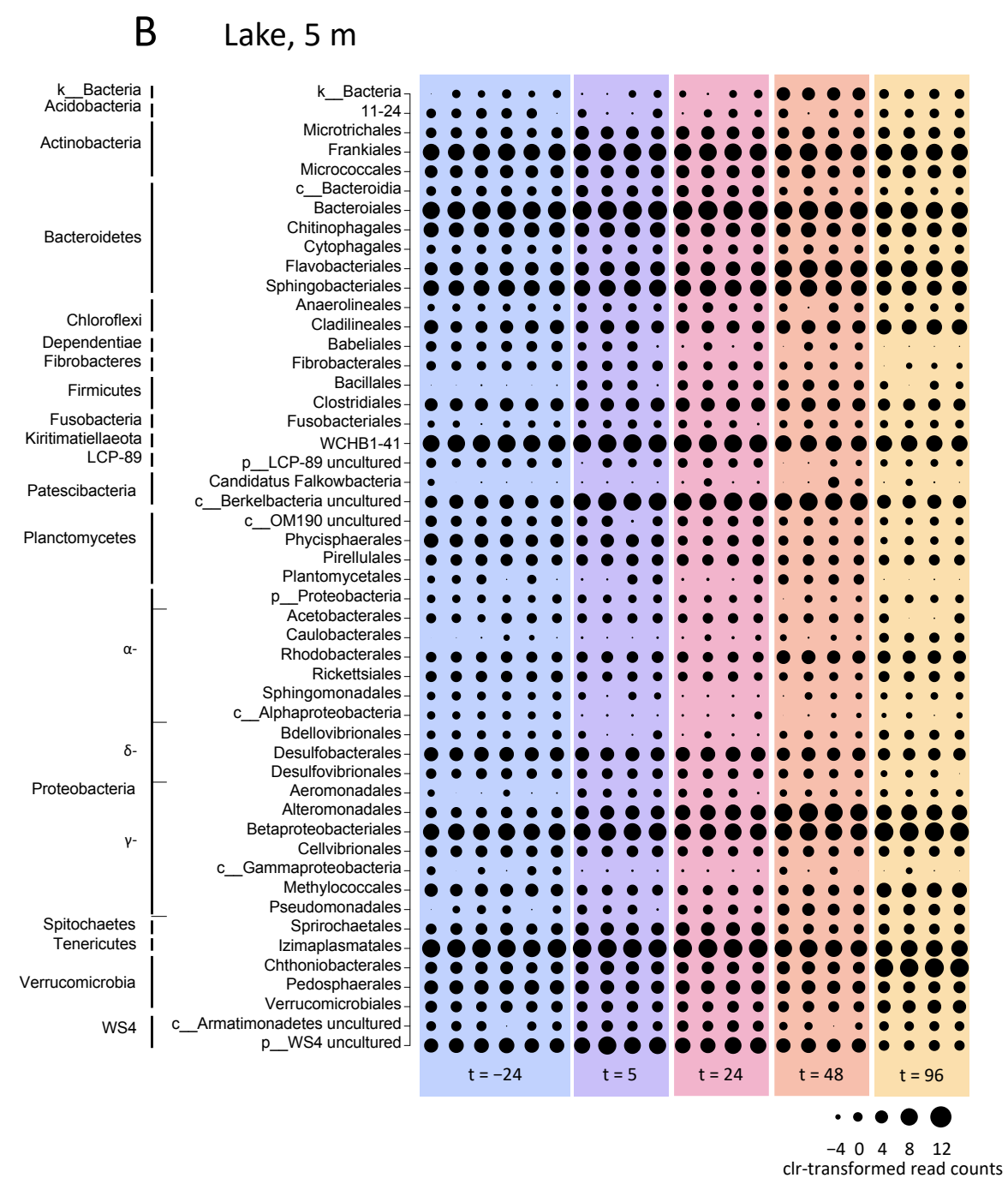

Figure 5. Microbial community composition during the lake treatment in August. Relative abundance shown as clr-transformed read counts at the phylum and order levels at (A) the 0-m and (B) 5-m depth during the lake treatment in August. Columns of the same color represent biological replicates at the same time point; columns of different colors represent different time points; " $\mathrm{k} \_$", " $\mathrm{p} \_$_ and "c__" indicate that the maximum classification of these taxa is at the kingdom, phylum and class level, respectively.

\subsubsection{Microbial Diversity}

The two alpha diversity indices, species richness (Chao-1) and phylogenetic diversity (Faith's PD), decreased significantly after the addition of $\mathrm{H}_{2} \mathrm{O}_{2}$ at both depths in the lake. The initial decline in alpha diversity, which reached the minimum at $24 \mathrm{~h}$ after the treatment, was followed by a strong and significant recovery after $48 \mathrm{~h}$ that even further increased after $96 \mathrm{~h}$, surpassing the diversity observed before the lake treatment (Figure 7A,B). Recovery of the microbial communities after the lake treatment was also indicated by the beta diversity analysis using Bray-Curtis dissimilarity matrices and unweighted UniFrac distance matrices. Strong shifts in the microbial communities after the treatment were followed by V-shaped recovery patterns along axis 2 of the PCoA plots both for Bray-Curtis dissimilarity (Figure 8A,B) and unweighted UniFrac distances (Figure 8C,D). 


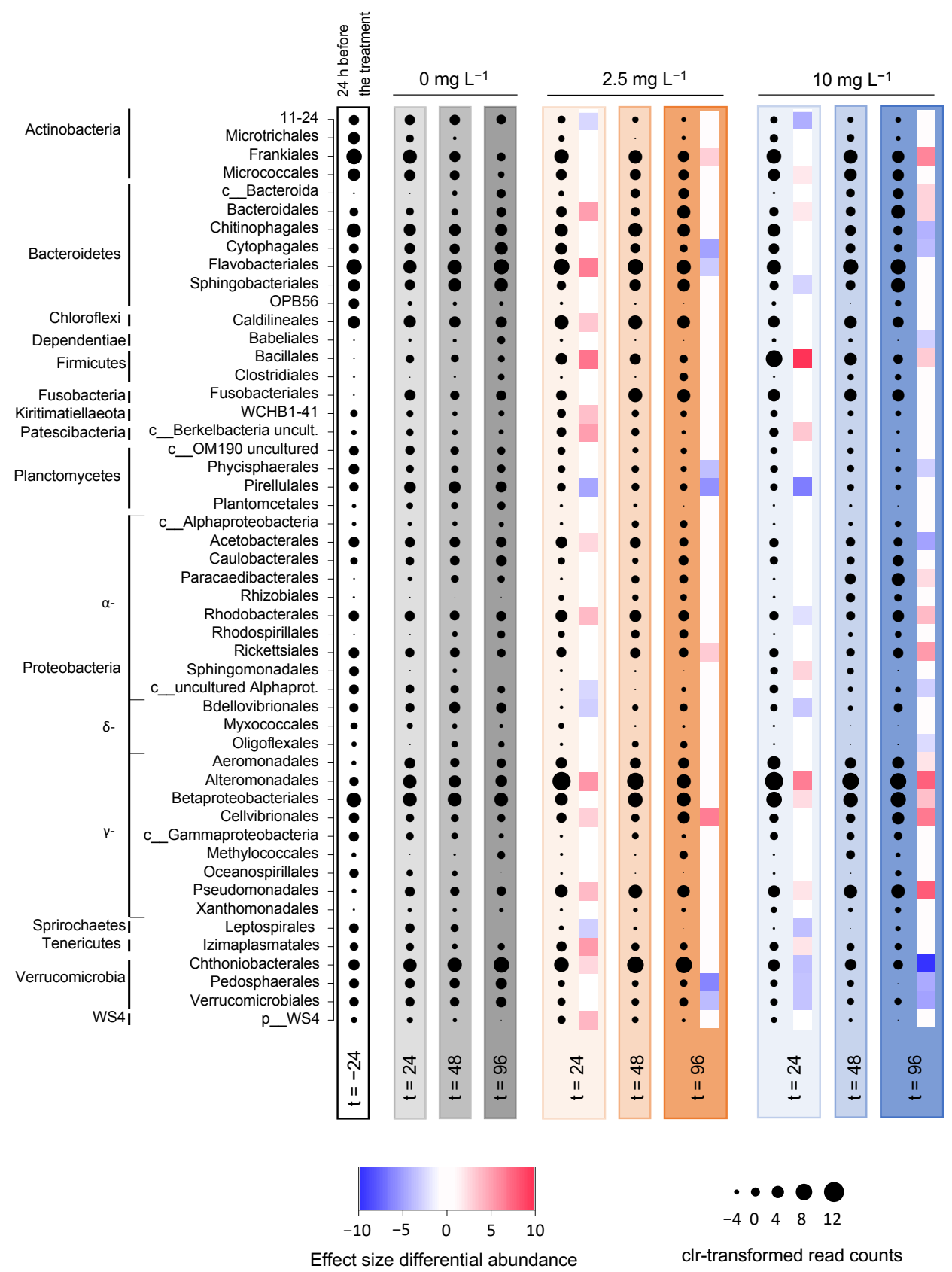

Figure 6. Microbial community composition during the incubation experiments in August. The graph shows the relative abundances as clr-transformed read counts of bacteria at the order level for each of the time points during the August treatment. The first column represents the average relative abundances in the lake prior to the incubation experiments $(t=-24 \mathrm{~h}$, with $n=$ seven biological replicates). The other columns represent the relative abundances in the incubation experiments at three subsequent time points $(\mathrm{t}=24,48$ and $96 \mathrm{~h}$, with $n=$ four biological replicates per time point). Gray columns represent the control incubations $\left(0 \mathrm{mg} \mathrm{L}^{-1} \mathrm{H}_{2} \mathrm{O}_{2}\right)$, orange columns-the $2.5 \mathrm{mg} \mathrm{L}^{-1}$ $\mathrm{H}_{2} \mathrm{O}_{2}$-treated incubations, blue columns-the $10 \mathrm{mg} \mathrm{L}^{-1} \mathrm{H}_{2} \mathrm{O}_{2}$-treated incubations. Differential abundances of orders between the treated and control incubations at $\mathrm{t}=24 \mathrm{~h}$ and $\mathrm{t}=96 \mathrm{~h}$ were calculated using ALDEx2. Effect sizes of the statistical test $(0.7 \times$ Cohen's $d)$ are shown in the heat map next to the $t=24$ and $t=96$ columns for all the significant comparisons; blue indicates a significant decrease in the relative abundance while red indicates a significant increase in the relative

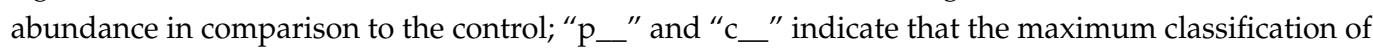
these taxa is at the phylum and class level, respectively. 
Diversity indices of the incubation bags showed very similar responses to $\mathrm{H}_{2} \mathrm{O}_{2}$ addition as in the lake. The Chao- 1 index and Faith's PD declined significantly $24 \mathrm{~h}$ after the treatment with $2.5 \mathrm{mg} \mathrm{L}^{-1}$ and $10 \mathrm{mg} \mathrm{L}^{-1} \mathrm{H}_{2} \mathrm{O}_{2}$, followed by a strong and significant recovery until the end of the experiment (Figure 7C,D). The beta diversity trajectories of the treated and control communities initially diverged but then converged during the subsequent 48-96 h. Convergence towards the community composition of the control is indicative of a strong recovery of the microbial communities. When analyzed using Bray-Curtis dissimilarity, a metric that takes relative abundances into account and therefore focuses on the more abundant features, the $2.5 \mathrm{mg} \mathrm{L}^{-1} \mathrm{H}_{2} \mathrm{O}_{2}$-treated communities showed a clear recovery whereas the trajectories suggested only a partial recovery for the $10 \mathrm{mg} \mathrm{L}^{-1} \mathrm{H}_{2} \mathrm{O}_{2}$ treatment (Figure $8 \mathrm{E}-\mathrm{G}$ ). When analyzed with unweighted UniFrac distances, a metric that focuses on the rarer features, a strong recovery was observed after the treatment with both $\mathrm{H}_{2} \mathrm{O}_{2}$ concentrations (Figure $8 \mathrm{H}-\mathrm{J}$ ).
Lake, $0 \mathrm{~m}$
Lake, $5 \mathrm{~m}$
Lake, $0 \mathrm{~m}$
Lake, $5 \mathrm{~m}$
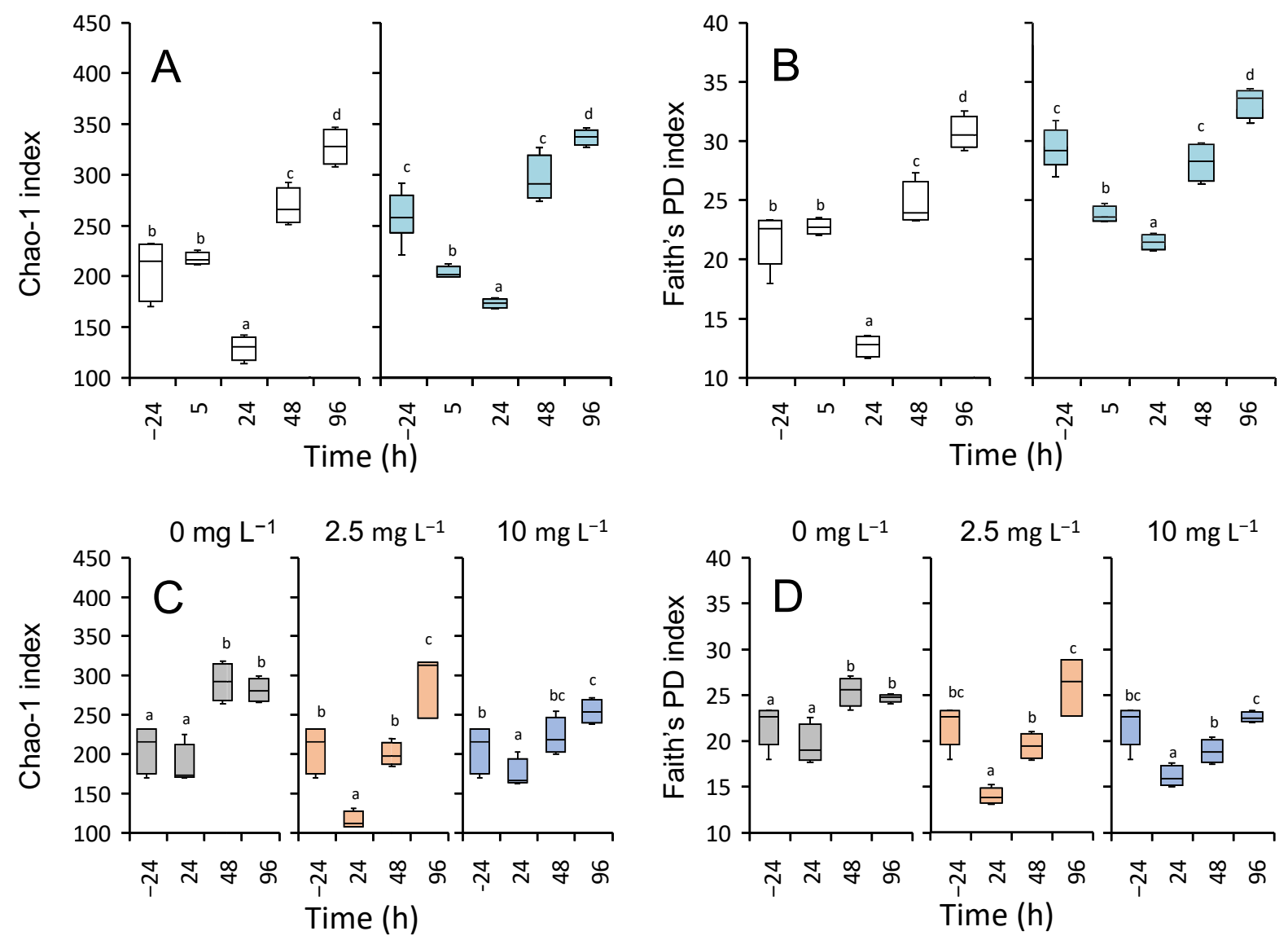

Figure 7. Alpha diversity of the microbial community during the $\mathrm{H}_{2} \mathrm{O}_{2}$ treatment in August. (A,C) The Chao-1 index (estimated species richness), and (B,D) Faith's phylogenetic diversity during (A,B) the lake treatment and (C,D) the incubation experiments in August. The color of the box plots indicates $(\mathbf{A}, \mathbf{B})$ the sampling depth in the lake or $(\mathbf{C}, \mathbf{D})$ the different $\mathrm{H}_{2} \mathrm{O}_{2}$ treatment concentrations of the incubations. The horizontal lines within the box plots represent the median, the boxes-the $25 \%$ quartile and the $75 \%$ quartile, error bars-the minimum values and the maximum values. The first box plot in each panel represents the alpha diversity in the lake prior to the incubation experiments $(\mathrm{t}=-24 \mathrm{~h}$, with $n=$ seven biological replicates). Box plots of all the subsequent time points are based on $n=$ four biological replicates. Box plots with different letters indicate significant differences between time points according to pairwise Kruskal-Wallis tests.

\subsubsection{Functional Prediction}

Both the Tax4Fun2 and PICRUSt2 analysis indicated that the $\mathrm{H}_{2} \mathrm{O}_{2}$ treatment of the lake had only a minor impact on the important ecological functions of the microbial com- 
munity, such as nitrogen and sulfur cycling. Specifically, the predicted relative abundances of the functional pathways (KEGG orthologs) for the production of glycoside hydrolases, nitrogen metabolism, sulfur metabolism and anti-ROS activity all remained stable at both depths in response to the lake treatment (Figure 9).
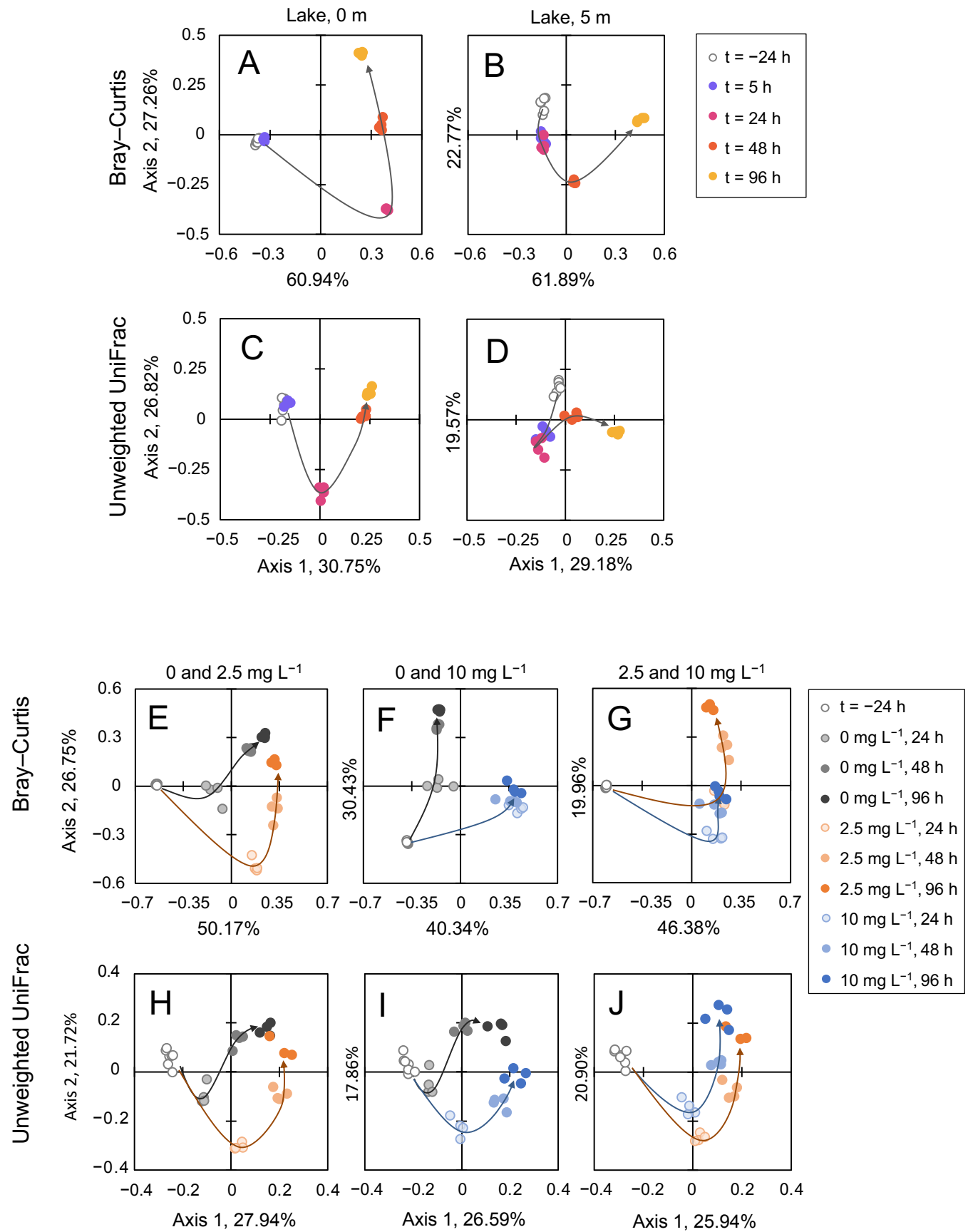

Figure 8. Beta diversity of the microbial community during the $\mathrm{H}_{2} \mathrm{O}_{2}$ treatment in August. PCoA plots of beta diversity of the microbial community during (A-D) the lake treatment and (E-J) the incubation experiments in August. Beta diversity in $(\mathbf{A}, \mathbf{B})$ and $(\mathbf{E}-\mathbf{G})$ is based on the Bray-Curtis dissimilarity matrix, in $(\mathbf{C}, \mathbf{D})$ and $(\mathbf{H}-\mathbf{J})$ - on the unweighted UniFrac distance matrix. Each symbol in the graph represents one sample; all samples with symbols of the same color are biological replicates. Gray open circles represent samples in the lake prior to the $\mathrm{H}_{2} \mathrm{O}_{2}$ treatment (i.e., the starting community at $\mathrm{t}=-24 \mathrm{~h}$ ). Arrows visualize the trajectories of the bacterial communities throughout the experiment. Pairwise PERMANOVAs revealed significant differences between all clusters within the same panel.

In the incubation experiments, several minor but significant differences were found between the $\mathrm{H}_{2} \mathrm{O}_{2}$ treatments and the control (Figure 10). At $24 \mathrm{~h}$, glycoside hydrolases 
and anti-ROS orthologs showed significantly higher relative abundances in the incubations treated with $\mathrm{H}_{2} \mathrm{O}_{2}$ than in the control according to both PICRUSt2 and Tax4Fun. Other significant differences were less consistent among the two pipelines. For instance, the relative abundance of the nitrogen metabolism was significantly higher in the $\mathrm{H}_{2} \mathrm{O}_{2}$ treatments than in the control according to PICRUSt2 (Figure 10A), whereas it was significantly lower according to Tax4Fun (Figure 10B). Overall, the predicted relative abundances of the functional pathways did not show major differences between the $\mathrm{H}_{2} \mathrm{O}_{2}$ treatments and the control.

A

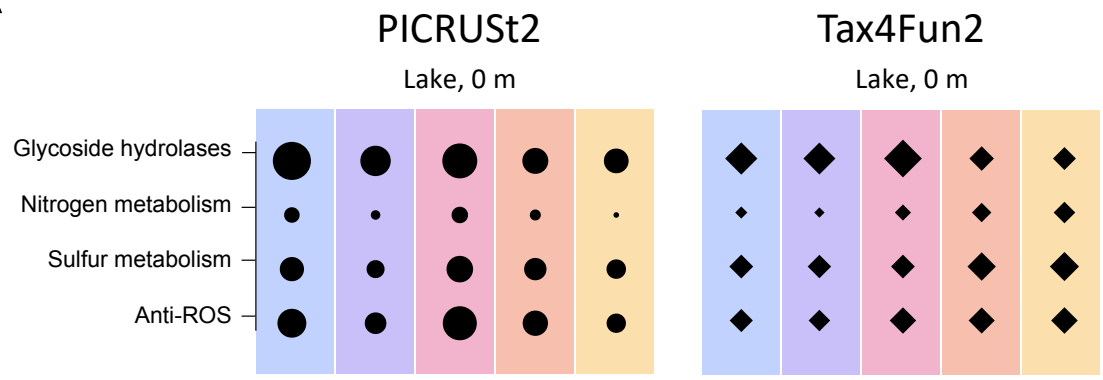

B

Lake, $5 \mathrm{~m}$

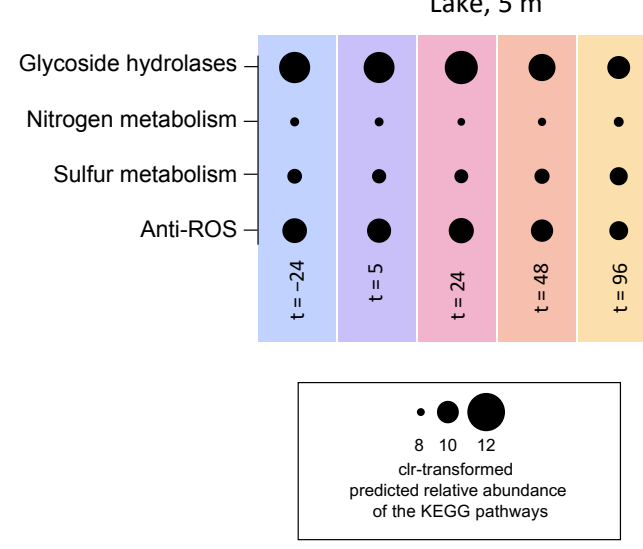

Lake, $5 \mathrm{~m}$
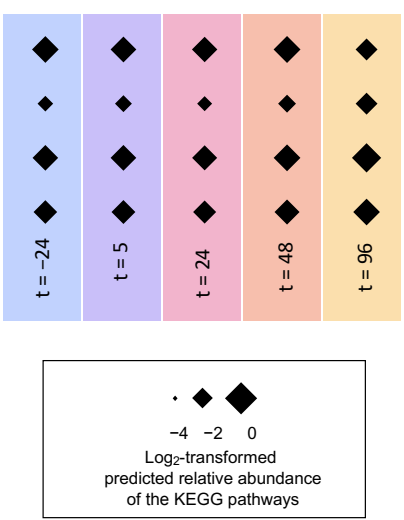

Figure 9. Functional prediction of the microbial community during the lake treatment in August. The graphs show predicted relative abundances of the selected KEGG orthologs or pathways for glycoside hydrolases, nitrogen and sulfur metabolism and anti-ROS enzymes at (A) the 0-m depth and (B) the 5-m depth during the lake treatment in August. The relative abundances of the selected KEGG orthologs or pathways were predicted by PICRUSt2 (circles) or Tax4Fun2 (triangles). The PICRUSt2 predictions are shown as clr-transformed counts while the Tax4Fun2 predictions are shown as $\log _{2}$-transformed percentages. Columns show the average of the predicted relative abundances of $n=$ seven biological replicates for the first time point $(\mathrm{t}=-24 \mathrm{~h})$ at the $0-\mathrm{m}$ depth, $n=$ six biological replicates for the first time point at the 5-m depth and $n=$ four biological replicates for all the other time points.

\subsection{Comparison of the June and August Treatments}

The lake treatments in June and August differed in subtle ways. The water temperature was lower and oxygen penetrated slightly deeper in June than in August (Figure S3). Furthermore, the measured $\mathrm{H}_{2} \mathrm{O}_{2}$ concentrations were slightly lower, and $\mathrm{H}_{2} \mathrm{O}_{2}$ degraded faster during the lake treatment in June (Figure S1) than during the lake treatment in August (Figure 2). The $\mathrm{N}$ and $\mathrm{P}$ nutrient dynamics were comparable for both lake treatments, with $\mathrm{NH}_{4}{ }^{+}$concentrations strongly increasing after the addition of $\mathrm{H}_{2} \mathrm{O}_{2}$ in both the June and August treatments while $\mathrm{NO}_{\mathrm{x}}$ and $\mathrm{PO}_{4}{ }^{3-}$ were much less affected (compare Figures S4 and S7). The phytoplankton community in June was largely dominated by the cyanobacterium Aphanizomenon klebahnii. Despite the fast $\mathrm{H}_{2} \mathrm{O}_{2}$ degradation, 
the June treatment led to an $89 \%$ decline of the biovolume of $A$. klebahnii within $48 \mathrm{~h}$ after $\mathrm{H}_{2} \mathrm{O}_{2}$ addition (Figure S8A,B).
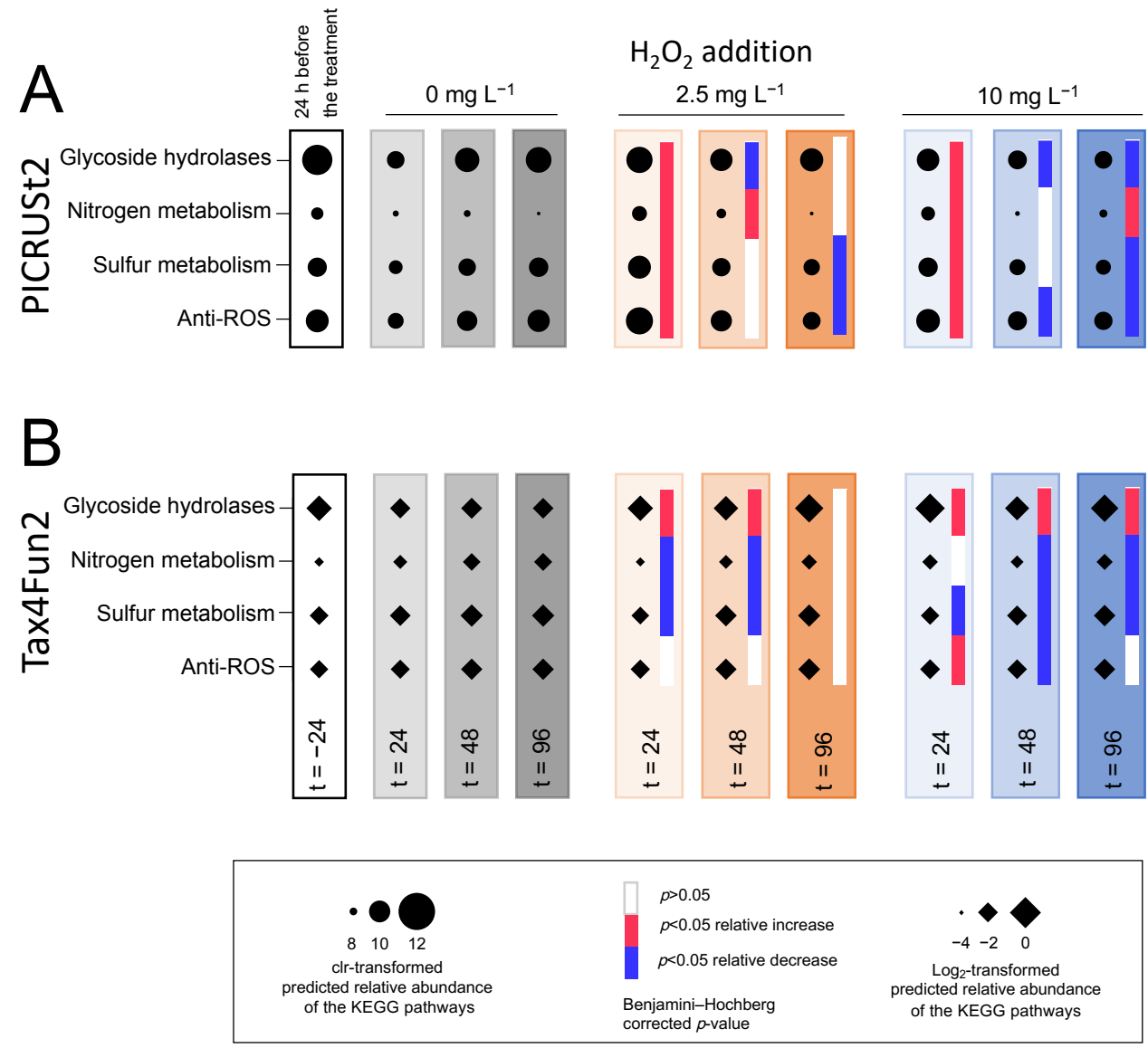

Figure 10. Functional prediction of the microbial community during the incubation experiments in August. The graphs show relative abundances of the selected KEGG orthologs or pathways for glycoside hydrolases, nitrogen and sulfur metabolism and anti-ROS enzymes during the incubation experiments in August as predicted by (A) PICRUSt2 and (B) Tax4Fun2. The first column presents relative abundances of the KEGG pathways in the lake prior to the incubation experiments $(\mathrm{t}=-24 \mathrm{~h}$, with $n=$ seven biological replicates). The other columns present relative abundances in the incubation experiments at the three subsequent time points $(\mathrm{t}=24,48$ and $96 \mathrm{~h}$, with $n=$ four biological replicates per time point). Gray columns represent the control incubations $\left(0 \mathrm{mg} \mathrm{L}^{-1} \mathrm{H}_{2} \mathrm{O}_{2}\right)$, orange columnsthe $2.5 \mathrm{mg} \mathrm{L}^{-1} \mathrm{H}_{2} \mathrm{O}_{2}$-treated incubations, blue columns-the $10 \mathrm{mg} \mathrm{L}^{-1} \mathrm{H}_{2} \mathrm{O}_{2}$-treated incubations. The color intensities of the columns represent different time points. Relative abundances are shown as (A) clr-transformed counts for PICRUSt2 and (B) $\log _{2}$-transformed percentages for Tax4Fun2. Significant differences in relative abundances at the same time point between the treated and control incubations were tested using (A) ALDEx2 and (B) the Wilcoxon test (see the Materials and Section 2 for details). Significant increases compared to the control are shown in red, significant decreases-in blue, in the heat map next to each time point. White fields in the heat map indicate that the relative abundances were not significantly different between the treated and control incubations.

The bacterial abundances in June were higher at $0 \mathrm{~m}$ than at the 5 - $\mathrm{m}$ depth (in contrast to August) and peaked 1 day later (Figure S9A). Most of the taxa that increased in relative abundance after the lake treatment in June (Flavobacteriales, Rhodobacterales, Alteromonadales and Pseudomonadales; Figure S10) were similar to those that increased in relative abundance after the lake treatment in August (Figure 5). In particular, the genera Flavobacterium (Flavobacteriales) and Rheinheimera (Alteromonadales) again codominated the microbial community at $24 \mathrm{~h}$ after $\mathrm{H}_{2} \mathrm{O}_{2}$ addition and again fell back to lower relative abundances during the subsequent days (Figure S11). Conversely, the taxa displaying 
a distinct decrease in the relative abundance after the June treatment (Bdellovibrionales and Bacteroidales at the 5-m depth) differed from the taxa that decreased after the August treatment (compare Figure 5 and Figure S10).

In the incubation experiments, many of the taxa responding significantly to the $\mathrm{H}_{2} \mathrm{O}_{2}$ treatments in June differed from those in August (compare Figure 6 and Figure S12). However, some taxa showed a more consistent pattern. Specifically, the genera Rheinheimera (Alteromonadales) and Pseudomonas (Pseudomonadales) reached significantly higher abundances in the $\mathrm{H}_{2} \mathrm{O}_{2}$ treatments than in the control, whereas Verrucomicrobia of the orders Chthoniobacterales and Pedosphaerales reached significantly lower abundances in response to $\mathrm{H}_{2} \mathrm{O}_{2}$ in both June and August (Figures S12 and S13).

Alpha diversity indices of species richness and phylogenetic diversity were similarly affected after the June and August treatments, with an initial decline during the first few days, followed by a strong recovery (Figure S14). As indicated by the beta diversity analysis, the lake microbial community composition in June also recovered, although beta diversity trajectories of the incubation experiments showed somewhat less convergence between the $\mathrm{H}_{2} \mathrm{O}_{2}$ treatments and the control in June than in August (Figure S15). Similarly to August, the predicted relative abundances of the functional pathways were not strongly affected during the $\mathrm{H}_{2} \mathrm{O}_{2}$ treatment in June (Figures S16 and S17). Again, the significance patterns of the incubation experiments were not fully consistent among the two pipelines (Figure S17). At 48 h, however, glycoside hydrolases, nitrogen metabolism and anti-ROS orthologs showed significantly higher relative abundances in the incubations treated with $\mathrm{H}_{2} \mathrm{O}_{2}$ than in the control according to both PICRUSt2 and Tax4Fun.

\section{Discussion}

\subsection{Effect of $\mathrm{H}_{2} \mathrm{O}_{2}$ on the Phytoplankton Community}

The results of this study confirm that low concentrations of $\mathrm{H}_{2} \mathrm{O}_{2}$ can effectively suppress cyanobacterial blooms. In both treatments, dominant cyanobacteria decreased rapidly, as shown by the decline of Aphanizomenon klebahnii in the June treatment and of Dolichospermum sp. in the August treatment. A fast decline of cyanobacterial blooms has also been observed in two previous $\mathrm{H}_{2} \mathrm{O}_{2}$ treatments of lakes dominated by Planktothrix agardhii [43] and Aphanizomenon flos-aquae [25]. During the August treatment, P. agardhii codominated the cyanobacterial bloom, but showed more resistance to $\mathrm{H}_{2} \mathrm{O}_{2}$ than Dolichospermum sp. Remarkably, in the incubation experiments with a starting concentration of $10 \mathrm{mg} \mathrm{L}^{-1}$, P. agardhii did not decline. A possible explanation for the strong persistence of P. agardhii in this study compared to Dolichospermum sp. and to P. agardhii in a previous lake treatment [43] might be the genetic variation in $\mathrm{H}_{2} \mathrm{O}_{2}$ sensitivity between the different strains as previously observed in both Planktothrix spp. [92] and Microcystis aeruginosa [93].

Eukaryotic dinoflagellate Ceratium spp. was abundant in the lake during the August treatment and was less affected by $\mathrm{H}_{2} \mathrm{O}_{2}$ than the cyanobacterium Dolichospermum sp. This observation is in line with many previous studies, which showed that cyanobacteria tend to be more resistant than eukaryotic phytoplankton species [19-26]. In contrast to the lake observations, Ceratium spp. declined in all the incubation experiments, including the control. Apparently, keeping Ceratium spp. in enclosed incubation bags was detrimental for this organism. The enclosed space may have disrupted their natural migrating behavior and likely caused their decline even in the control without $\mathrm{H}_{2} \mathrm{O}_{2}$. Ceratium spp. are good swimmers and known to form subsurface maxima by vertical migration during high light conditions [94].

Simultaneous investigation of the zooplankton community showed that the $\mathrm{H}_{2} \mathrm{O}_{2}$ treatment of the lake negatively affected rotifers, small zooplankton known to graze on bacteria and small phytoplankton $[95,96]$. In contrast, cladocerans and copepods, which can also graze on bacteria but mainly feed on larger phytoplankton size classes [96,97], were not affected by the $\mathrm{H}_{2} \mathrm{O}_{2}$ concentrations administered to the lake (personal communication, Weenink and Visser). 


\subsection{Bacterial Response to the $\mathrm{H}_{2} \mathrm{O}_{2}$ Treatment}

The bacterial abundances observed in this study before the $\mathrm{H}_{2} \mathrm{O}_{2}$ treatment $\left(0.5-6 \times 10^{6}\right.$ cells $\mathrm{mL}^{-1}$; Figure 4 and Figure S9) are comparable to the earlier published values for freshwater lakes $[98,99]$. Overall, the bacterial numbers were not much affected by the $\mathrm{H}_{2} \mathrm{O}_{2}$ treatment, except for a temporary ca. threefold increase within 1-2 days after the treatment. The peak in bacterial abundance coincided with a temporary decline in alpha diversity, shifts in beta diversity, increasing ammonium concentrations and increases in the relative abundance of anti-ROS and glycoside hydrolase orthologs. Glycoside hydrolases are enzymes involved in the degradation of the polysaccharides derived from plant and algal biomass such as glycogen, cellulose and starch, whereas ammonium is released by the degradation of $\mathrm{N}$-rich molecules such as proteins. Hence, these results indicate that some bacteria with adequate $\mathrm{H}_{2} \mathrm{O}_{2}$ protection mechanisms temporarily profited from the degradation of organic compounds released by the lysing cyanobacterial bloom. The subsequent return to lower bacterial abundances might be a consequence of the temporary nature of the lysis event, additional losses (grazing), altered organic carbon sources due to the strongly changed phytoplankton composition or linked to the changing environmental conditions in the lake (such as the decline in temperature, oxygen saturation and $\mathrm{pH}$ ) [100].

\subsection{Effect of $\mathrm{H}_{2} \mathrm{O}_{2}$ on Microbial Community Composition}

Many of the dominant bacterial phyla of lake Oosterduinse Meer detected by our primer set are also common in other freshwater lakes around the world [22,26,101-104]. However, the microbial community composition of lakes is known to vary substantially throughout the seasons and often in accordance with changing environmental conditions $[98,102,103,105]$, as reflected by the differences in community composition between both treatments of this study. Hence, the impacts of $\mathrm{H}_{2} \mathrm{O}_{2}$ treatments should be interpreted against the background of natural changes in microbial community composition.

Some taxa consistently increased in the relative abundance after exposure to $\mathrm{H}_{2} \mathrm{O}_{2}$, both in the lake treatments and in the controlled incubation experiments. In particular, several members of the Proteobacteria strongly increased in relative abundance, as also observed in the recent studies of Lusty and Gobler [26] and Santos et al. [42]. In our study, these members included Alteromonadales (Gammaproteobacteria) of the genus Rheinheimera, which have been found to produce $\mathrm{H}_{2} \mathrm{O}_{2}$ themselves [106], as well as Pseudomonadales, which have also been described to be very resistant against oxidative stress [107]. Both Rheinheimera and Pseudomonadales also increased in relative abundance after $\mathrm{H}_{2} \mathrm{O}_{2}$ treatments in the field mesocosm study of Lin et al. [22]. Amongst Alphaproteobacteria, Rhodobacterales repeatedly increased in relative abundance after $\mathrm{H}_{2} \mathrm{O}_{2}$ exposure in this study, which is in line with the results in the $2 \mathrm{mg} \mathrm{L}^{-1} \mathrm{H}_{2} \mathrm{O}_{2}$-treated field mesocosms of Lin et al. [22] and the increase of Paracoccus (Rhodobacteraceae) in the mesocosm experiments of Santos et al. [42]. This is not surprising given that members of Rhodobacterales master a wide range of growth mechanisms, from photoautotrophy and (an-)aerobic respiration to fermentation, and this flexibility may enable them to rapidly respond to changing environmental conditions [108-110]. Contrary to our results, both Lusty and Gobler [26] and Santos et al. [42] reported a decrease in the relative abundance of Actinobacteria in outdoor incubation experiments with lake water after addition of $\mathrm{H}_{2} \mathrm{O}_{2}$. While small decreases in relative abundance were observed for Microtrichales during the June incubations and after the August lake treatment, most orders of the phylum Actinobacteria were rather stable or increased in response to the $\mathrm{H}_{2} \mathrm{O}_{2}$ treatments (e.g., the order of Frankiales).

Only a few taxa showed a consistently lower relative abundance after exposure to $\mathrm{H}_{2} \mathrm{O}_{2}$ in the incubation experiments, including three orders of the phylum Verrucomicrobia (i.e., Chthoniobacterales, Pedosphaerales and, to a lesser extent, Verrucomicrobiales). This agrees with previous observations that Verrucomicrobia suffered from $\mathrm{H}_{2} \mathrm{O}_{2}$ treatments $[22,26,42]$. However, the increase in the relative abundance of Chthoniobacterales within the lake two to four days after the August treatment (Figure 5) seems to contrast their decline in the incubation experiments (Figure 6). Chthoniobacterales belong 
to Spartobacteria, a class of heterotrophic Verrucomicrobia inhabiting soils and aquatic environments [111,112]. A metagenomic study in the Baltic Sea found that Spartobacteria produced a large diversity of glycoside hydrolases targeting a variety of carbohydrates and observed a close association of Spartobacteria with cyanobacteria that may have produced carbohydrate substrates [113]. Hence, a potential explanation for our observations might be that Chthoniobacterales are first temporarily suppressed by $\mathrm{H}_{2} \mathrm{O}_{2}$, but benefit from storage and structural polysaccharides [114] released by the lysing cyanobacterial bloom once the added $\mathrm{H}_{2} \mathrm{O}_{2}$ has disappeared.

\subsection{Community Resilience after the Treatment with $\mathrm{H}_{2} \mathrm{O}_{2}$}

Changes in the microbial community in response to disturbances are best described by the terms "resistance" and "resilience." Resistance describes the degree to which a community can remain unchanged during a disturbance, whereas the resilience of a community describes the rate of recovery after a disturbance [115]. Disturbances to the ecosystem can have both positive and negative effects on alpha diversity $[102,116,117]$ and sometimes even opposite effects in the epilimnion and hypolimnion of the same lake [100]. The microbial communities in the lake and the incubation experiments were not resistant to the $\mathrm{H}_{2} \mathrm{O}_{2}$ treatments as indicated by a strong decrease in species richness as well as phylogenetic diversity (Figure 7 and Figure S14), but alpha diversity also recovered within a few days. This temporary response was also visible in the shifts in community composition in both the lake treatment and the incubation experiments, where Rheinheimera and Flavobacterium strongly increased in relative abundance during the first $24 \mathrm{~h}$ after $\mathrm{H}_{2} \mathrm{O}_{2}$ addition but subsequently declined again. The temporary negative effect on alpha diversity and concomitant shift in microbial community composition might be explained by the very nature of $\mathrm{H}_{2} \mathrm{O}_{2}$ treatments. Unlike most other chemical treatments, added $\mathrm{H}_{2} \mathrm{O}_{2}$ rapidly degrades to water and oxygen and hence disappears from the lake within a few days. In ecological terms, $\mathrm{H}_{2} \mathrm{O}_{2}$ treatments thus represent pulse (short-term) disturbances rather than press (long-term) disturbances [118,119]. After the added $\mathrm{H}_{2} \mathrm{O}_{2}$ has disappeared, the microbial community can recover. Strong resilience of the species richness and phylogenetic diversity observed in the lake and in the incubations indicates that most taxa survived the applied concentrations of $\mathrm{H}_{2} \mathrm{O}_{2}$ and were temporarily suppressed rather than removed from the ecosystem. Similar alpha diversity resilience patterns of microbial communities have been reported for a variety of other ecosystems, including freshwater lakes, after other pulse disturbances $[100,115,120]$.

High resilience after the $\mathrm{H}_{2} \mathrm{O}_{2}$ treatments was also visible from the analysis of beta diversity in the lake (Figure 8 and Figure S11). The microbial communities recovered mostly in a V-shaped pattern for both the dissimilarity and the distance matrices. This indicates that the community after the lake $\mathrm{H}_{2} \mathrm{O}_{2}$ treatment did not return to the exact same starting point but rather to a slightly altered community composition similar to the previously observed after other pulse disturbances [100,121]. Most likely, this V-shaped recovery is caused by altered environmental conditions during the days after the treatment such as a change in weather conditions leading to an increased mixing depth of the lake $[100,104]$. In contrast to laboratory or incubation experiments, spatial refuges for bacteria in lakes likely facilitate the resilience of microbial communities [121], e.g., close to the sediment in shallow parts of the lake where $\mathrm{H}_{2} \mathrm{O}_{2}$ degradation rates are strongly increased.

In contrast to whole lake treatment, incubation treatments allow for experimental replication and the inclusion of controls without $\mathrm{H}_{2} \mathrm{O}_{2}$. The beta diversity analysis of the incubation experiments confirmed the $\mathrm{V}$-shaped recovery pattern observed in the lake. In addition, it showed that not only the treated communities were shifting towards a new, altered composition, but also the community composition of the untreated control communities was shifting in the same direction. While it remains uncertain to what extent the shift of the control communities was due to natural processes or, rather, due to the so-called "bottle effect" [122], the convergence of the trajectories of the treated and control communities demonstrates strong resilience of the communities after $\mathrm{H}_{2} \mathrm{O}_{2}$ additions. 


\subsection{Microbial Functions Show Resistance after the Treatment with $\mathrm{H}_{2} \mathrm{O}_{2}$}

$\mathrm{H}_{2} \mathrm{O}_{2}$ had only minor effects on the functional pathways investigated in this study. The strong resistance to $\mathrm{H}_{2} \mathrm{O}_{2}$ treatments indicated by the prediction of stable relative abundances of the functional pathways (KEGG orthologs) by both pipelines is likely due to redundancy in functionality within microbial communities [115,123].

It is important to point out that the functional predictions were not always consistent between both pipelines and therefore require careful interpretation. Functional predictions based on the $16 \mathrm{~S}$ rRNA gene amplicon sequencing data have strongly improved in recent years, including due to expanded reference databases of pipelines like Tax4fun2 and PICRUSt2 $[86,87]$. However, the prediction accuracy is tightly linked to the coverage of those reference databases, in which freshwater environments are still strongly underrepresented [86,124]. For more accurate analyses of the functional profiles of freshwater microbial communities, metagenomic and metatranscriptomic studies would be required. Despite the increasing use of metagenome reference databases to assess microbial functions in freshwater environments [125-128], a strong degree of uncertainty of the functional predictions is so far unavoidable.

Both pipelines indicated that the $\mathrm{H}_{2} \mathrm{O}_{2}$ treatments were accompanied by a temporary increase in the relative abundance of the pathways representing anti-ROS enzymes and glycoside hydrolases. The consistency of this pattern, which was apparent in the incubation experiments in both June and August, suggests that this result is robust. A temporary increase of taxa with the anti-ROS pathways signifies that effective $\mathrm{H}_{2} \mathrm{O}_{2}$ defense mechanisms play a role in the resistance to $\mathrm{H}_{2} \mathrm{O}_{2}$ treatment [129]. In addition, possessing glycoside hydrolases to break down organic matter released by the decaying cyanobacterial bloom undoubtedly offers a clear advantage during the first few days after the treatment $[56,114,130]$.

\section{Conclusions}

The whole lake $\mathrm{H}_{2} \mathrm{O}_{2}$ treatments effectively suppressed the dominant cyanobacteria Aphanizomenon klebahnii, Dolichospermum sp. and, to a lesser extent, Planktothrix agardhii. Analysis of the microbial community composition with primers that do not target cyanobacteria revealed that the $\mathrm{H}_{2} \mathrm{O}_{2}$ concentrations used in this study had a distinct temporary effect on the microbial community. The taxa that are known to be resistant to oxidative stress (e.g., Rheinheimera) were favored during the first $24 \mathrm{~h}$ after $\mathrm{H}_{2} \mathrm{O}_{2}$ addition, but subsequently their relative abundance declined again. The applied $\mathrm{H}_{2} \mathrm{O}_{2}$ concentrations thus represented a short-term pulse disturbance, which caused a temporary decline in alpha and beta diversity and a temporary increase of the functional pathways encoding anti-ROS defenses and glycoside hydrolases. However, the microbial community proved to be resilient and recovered a few days after the treatments.

Supplementary Materials: The following are available online at https: / www.mdpi.com/article / 10.3390/microorganisms9071495/s1, Figure S1: H2O2 treatment of the lake, Figure S2: Run-to-run variation, Figure S3: Environmental variables measured during the $\mathrm{H} 2 \mathrm{O} 2$ treatments, Figure S4: Dissolved inorganic nutrients during the $\mathrm{H} 2 \mathrm{O} 2$ treatment in August, Figure S5: Microbial community composition at the genus level during the lake treatment in August, Figure S6: Microbial community composition at the genus level during the incubation experiments in August, Figure S7: Dissolved inorganic nutrients during the $\mathrm{H} 2 \mathrm{O} 2$ treatment in June, Figure S8: Phytoplankton composition during the $\mathrm{H} 2 \mathrm{O} 2$ treatment in June, Figure S9: Total bacterial abundances during the $\mathrm{H} 2 \mathrm{O} 2$ treatment in June, Figure S10: Microbial community composition at the order level during the lake treatment in June, Figure S11: Microbial community composition at the genus level during the lake treatment in June, Figure S12: Microbial community composition at the order level during the incubation experiments in June, Figure S13: Microbial community composition at the genus level during the incubation experiments in June, Figure S14: Alpha diversity of the microbial community during the $\mathrm{H} 2 \mathrm{O} 2$ treatment in June, Figure S15: Beta diversity of the microbial community during the $\mathrm{H} 2 \mathrm{O} 2$ treatment in June, Figure S16: Functional prediction of the microbial community during the lake treatment in June, Figure S17: Functional prediction of the microbial community during the 
incubation experiments in June, Table S1: Overview of the accession numbers and metadata of the $16 \mathrm{~S}$ rRNA amplicon sequences deposited at the ENA, Table S2: Weather data during the treatments in June and August, Table S3: Feature tables of the microbial community at the genus level for the lake treatments and the incubation experiments.

Author Contributions: Conceptualization, T.P., G.S., G.M., C.P.D.B., J.H. and P.M.V.; Formal analysis, T.P. and G.S.; Investigation, T.P. and G.S.; Resources, P.C.S. and M.J.v.H.; Data curation, T.P. and G.S.; Writing—original draft preparation, T.P.; Writing—review and editing, G.S., G.M., C.P.D.B., P.C.S. M.J.v.H., J.H. and P.M.V.; Visualization, T.P.; Supervision, J.H. and P.M.V.; Project administration, P.M.V.; Funding acquisition, C.P.D.B., J.H. and P.M.V. All authors have read and agreed to the published version of the manuscript.

Funding: This research was funded by the Dutch Research Council (NWO), project number 14005.

Institutional Review Board Statement: Not applicable.

Informed Consent Statement: Not applicable.

Data Availability Statement: The sequence data for this study were deposited in the European Nucleotide Archive (ENA) at the EMBL-EBI under accession number PRJEB44985 (https:/ / www.ebi. ac.uk/ena/browser/view/PRJEB44985; accessed on 6 April 2021).

Acknowledgments: We thank Erik Weenink, Hongjie Qin, Mariël Léon Morales-Grooters, Bas van Beusekom, J. Merijn Schuurmans, Sinead Kinsella, Catarina Cúcio, Xing Ji, Corné van Teulingen, Anne-Catharine Ahn, Anouk Milewski, Tijs Joling, Avila Lindgren, Nina Witteveen and Suzanne de Zwaan for their help with sample collection and sample processing during the lake treatments. Special thanks go to Hoogheemraadschap Rijnland for their cooperation and support during the lake treatments and to Arcadis for providing and maintaining a specialized boat and dedicated crew that enabled the careful and safe treatment of the lake.

Conflicts of Interest: The authors declare no conflict of interest.

\section{References}

1. Michalak, A.M.; Anderson, E.J.; Beletsky, D.; Boland, S.; Bosch, N.S.; Bridgeman, T.B.; Chaffin, J.D.; Cho, K.; Confesor, R.; Daloglu, I.; et al. Record-setting algal bloom in Lake Erie caused by agricultural and meteorological trends consistent with expected future conditions. Proc. Natl. Acad. Sci. USA 2013, 110, 6448-6452. [CrossRef]

2. Hamilton, D.P.; Wood, S.A.; Dietrich, D.R.; Puddick, J. Costs of harmful blooms of freshwater cyanobacteria. In Cyanobacteria: An Economic Perspective; Naveen, K.S., Rai, A.K., Stal, L.J., Eds.; Wiley Online Library: Chichester, UK, 2014 ; pp. $247-256$.

3. Sanseverino, I.; Conduto, D.; Pozzoli, L.; Dobricic, S.; Lettieri, T. Algal Bloom and Its Economic Impact. Eur. Comm. Jt. Res. Cent. Inst. Environ. Sustain. 2016, EUR 27905 EN, 1-48. [CrossRef]

4. Huisman, J.; Codd, G.A.; Paerl, H.W.; Ibelings, B.W.; Verspagen, J.M.H.; Visser, P.M. Cyanobacterial blooms. Nat. Rev. Microbiol. 2018, 16, 471-483. [CrossRef] [PubMed]

5. Carmichael, W.W. Health effects of toxin-producing cyanobacteria: “The CyanoHABs”. Hum. Ecol. Risk Assess. (HERA) 2001, 7, 1393-1407. [CrossRef]

6. Codd, G.A.; Morrison, L.F.; Metcalf, J.S. Cyanobacterial toxins: Risk management for health protection. Toxicol. Appl. Pharmacol. 2005, 203, 264-272. [CrossRef] [PubMed]

7. Poste, A.E.; Hecky, R.E.; Guildford, S.J. Evaluating microcystin exposure risk through fish consumption. Environ. Sci. Technol. 2011, 45, 5806-5811. [CrossRef] [PubMed]

8. Bukaveckas, P.A.; Lesutienè, J.; Gasiūnaitè, Z.R.; Ložys, L.; Olenina, I.; Pilkaitytè, R.; Pūtys, Ž.; Tassone, S.; Wood, J. Microcystin in aquatic food webs of the Baltic and Chesapeake Bay Regions. Estuar. Coast. Shelf Sci. 2017, 191, 50-59. [CrossRef]

9. Visser, P.M.; Ibelings, B.W.; Bormans, M.; Huisman, J. Artificial mixing to control cyanobacterial blooms: A review. Aquat. Ecol. 2016, 50, 423-441. [CrossRef]

10. Ho, J.C.; Michalak, A.M.; Pahlevan, N. Widespread global increase in intense lake phytoplankton blooms since the 1980s. Nature 2019, 574, 667-670. [CrossRef]

11. O'Neil, J.M.; Davis, T.W.; Burford, M.A.; Gobler, C.J. The rise of harmful cyanobacteria blooms: The potential roles of eutrophication and climate change. Harmful Algae 2012, 14, 313-334. [CrossRef]

12. Paerl, H.W.; Huisman, J. Climate: Blooms like it hot. Science 2008, 320, 57-58. [CrossRef]

13. Jeppesen, E.; Søndergaard, M.; Jensen, J.P.; Havens, K.E.; Anneville, O.; Carvalho, L.; Coveney, M.F.; Deneke, R.; Dokulil, M.T.; Foy, B.; et al. Lake responses to reduced nutrient loading: An analysis of contemporary long-term data from 35 case studies. Freshw. Biol. 2005, 50, 1747-1771. [CrossRef] 
14. Fastner, J.; Abella, S.; Litt, A.; Morabito, G.; Vörös, L.; Pálffy, K.; Straile, D.; Kümmerlin, R.; Matthews, D.; Phillips, M.G.; et al. Combating cyanobacterial proliferation by avoiding or treating inflows with high P load: Experiences from eight case studies. Aquat. Ecol. 2016, 50, 367-383. [CrossRef]

15. Hamilton, D.P.; Salmaso, N.; Paerl, H.W. Mitigating harmful cyanobacterial blooms: Strategies for control of nitrogen and phosphorus loads. Aquat. Ecol. 2016, 50, 351-366. [CrossRef]

16. Søndergaard, M.; Jensen, J.P.; Jeppesen, E. Role of sediment and internal loading of phosphorus in shallow lakes. Hydrobiologia 2003, 506-509, 135-145. [CrossRef]

17. Ibelings, B.W.; Bormans, M.; Fastner, J.; Visser, P.M. Cyanocost Special Issue on Cyanobacterial Blooms: Synopsis-A critical review of the management options for their prevention, control and mitigation. Aquat. Ecol. 2016, 50, 595-605. [CrossRef]

18. Paerl, H.W. Mitigating toxic planktonic cyanobacterial blooms in aquatic ecosystems facing increasing anthropogenic and climatic pressures. Toxins 2018, 10, 76. [CrossRef]

19. Barroin, G.; Feuillade, M. Hydrogen peroxide as a potential algicide for Oscillatoria rubescens D.C. Water Res. 1986, 20, 619-623. [CrossRef]

20. Drábková, M.; Admiraal, W.; Maršálek, B. Combined exposure to hydrogen peroxide and light-selective effects on cyanobacteria, green algae, and diatoms. Environ. Sci. Technol. 2007, 41, 309-314. [CrossRef]

21. Kumar Sinha, A.; Eggleton, M.A.; Lochmann, R.T. An environmentally friendly approach for mitigating cyanobacterial bloom and their toxins in hypereutrophic ponds: Potentiality of a newly developed granular hydrogen peroxide-based compound. Sci. Total Environ. 2018, 637-638, 524-537. [CrossRef]

22. Lin, L.; Shan, K.; Xiong, Q.; Zhou, Q.; Li, L.; Gan, N.; Song, L. The ecological risks of hydrogen peroxide as a cyanocide: Its effect on the community structure of bacterioplankton. J. Oceanol. Limnol. 2018, 36, 2231-2242. [CrossRef]

23. Yang, Z.; Buley, R.P.; Fernandez-Figueroa, E.G.; Barros, M.U.G.; Rajendran, S.; Wilson, A.E. Hydrogen peroxide treatment promotes chlorophytes over toxic cyanobacteria in a hyper-eutrophic aquaculture pond. Environ. Pollut. 2018, 240, 590-598. [CrossRef]

24. Wang, B.; Song, Q.; Long, J.; Song, G.; Mi, W.; Bi, Y. Optimization method for Microcystis bloom mitigation by hydrogen peroxide and its stimulative effects on growth of chlorophytes. Chemosphere 2019, 228, 503-512. [CrossRef]

25. Weenink, E.F.J.; Matthijs, H.C.P.; Schuurmans, J.M.; Piel, T.; Herk, M.J.; Sigon, C.A.M.; Visser, P.M.; Huisman, J. Interspecific protection against oxidative stress: Green algae protect harmful cyanobacteria against hydrogen peroxide. Environ. Microbiol. 2021, 23, 2404-2419. [CrossRef]

26. Lusty, M.W.; Gobler, C.J. The efficacy of hydrogen peroxide in mitigating cyanobacterial blooms and altering microbial communities across four lakes in NY, USA. Toxins 2020, 12, 428. [CrossRef]

27. Matthijs, H.C.P.; Jančula, D.; Visser, P.M.; Maršálek, B. Existing and emerging cyanocidal compounds: New perspectives for cyanobacterial bloom mitigation. Aquat. Ecol. 2016, 50, 443-460. [CrossRef]

28. Mehler, A.H. Studies on reactions of illuminated chloroplasts: I. Mechanism of the reduction of oxygen and other Hill reagents. Arch. Biochem. Biophys. 1951, 33, 65-77. [CrossRef]

29. Asada, K. The water-water cycle in chloroplasts: Scavenging of active oxygens and dissipation of excess photons. Annu. Rev. Plant Physiol. Plant Mol. Biol. 1999, 50, 601-639. [CrossRef] [PubMed]

30. Helman, Y.; Tchernov, D.; Reinhold, L.; Shibata, M.; Ogawa, T.; Schwarz, R.; Ohad, I.; Kaplan, A. Genes encoding A-type flavoproteins are essential for photoreduction of $\mathrm{O}_{2}$ in Cyanobacteria. Curr. Biol. 2003, 13, 230-235. [CrossRef]

31. Allahverdiyeva, Y.; Isojärvi, J.; Zhang, P.; Aro, E.M. Cyanobacterial oxygenic photosynthesis is protected by flavodiiron proteins. Life 2015, 5, 716-743. [CrossRef] [PubMed]

32. Drábková, M.; Matthijs, H.C.P.; Admiraal, W.; Maršálek, B. Selective effects of $\mathrm{H}_{2} \mathrm{O}_{2}$ on cyanobacterial photosynthesis. Photosynthetica 2007, 45, 363-369. [CrossRef]

33. Blot, N.; Mella-Flores, D.; Six, C.; le Corguillé, G.; Boutte, C.; Peyrat, A.; Monnier, A.; Ratin, M.; Gourvil, P.; Campbell, D.A.; et al. Light history influences the response of the marine cyanobacterium Synechococcus sp. WH7803 to oxidative stress. Plant Physiol. 2011, 156, 1934-1954. [CrossRef] [PubMed]

34. Mikula, P.; Zezulka, S.; Jančula, D.; Maršálek, B. Metabolic activity and membrane integrity changes in Microcystis aeruginosa: New findings on hydrogen peroxide toxicity in cyanobacteria. Eur. J. Phycol. 2012, 47, 195-206. [CrossRef]

35. Lürling, M.; Meng, D.; Faassen, E.J. Effects of hydrogen peroxide and ultrasound on biomass reduction and toxin release in the cyanobacterium, Microcystis aeruginosa. Toxins 2014, 6, 3260-3280. [CrossRef] [PubMed]

36. Papadimitriou, T.; Kormas, K.; Dionysiou, D.D.; Laspidou, C. Using $\mathrm{H}_{2} \mathrm{O}_{2}$ Treatments for the degradation of cyanobacteria and microcystins in a shallow hypertrophic reservoir. Environ. Sci. Pollut. Res. 2016, 23, 21523-21535. [CrossRef]

37. Daniel, E.; Weiss, G.; Murik, O.; Sukenik, A.; Lieman-Hurwitz, J.; Kaplan, A. The response of Microcystis aeruginosa strain MGK to a single or two consecutive $\mathrm{H}_{2} \mathrm{O}_{2}$ applications. Environ. Microbiol. Rep. 2019, 11, 621-629. [CrossRef] [PubMed]

38. Piel, T.; Sandrini, G.; White, E.; Xu, T.; Schuurmans, J.M.; Huisman, J.; Visser, P.M. Suppressing cyanobacteria with hydrogen peroxide is more effective at high light intensities. Toxins 2020, 12, 18. [CrossRef]

39. Sandrini, G.; Piel, T.; Xu, T.; White, E.; Qin, H.; Slot, P.C.; Huisman, J.; Visser, P.M. Sensitivity to hydrogen peroxide of the bloom-forming cyanobacterium Microcystis PCC 7806 depends on nutrient availability. Harmful Algae 2020, 99, 101916. [CrossRef] 
40. Keliri, E.; Paraskeva, C.; Sofokleous, A.; Sukenik, A.; Dziga, D.; Chernova, E.; Brient, L.; Antoniou, M.G. Occurrence of a single-species cyanobacterial bloom in a lake in Cyprus: Monitoring and treatment with hydrogen peroxide-releasing granules. Environ. Sci. Eur. 2021, 33, 31. [CrossRef]

41. Chen, C.; Wang, Y.; Chen, K.; Shi, X.; Yang, G. Using hydrogen peroxide to control cyanobacterial blooms: A mesocosm study focused on the effects of algal density in Lake Chaohu, China. Environ. Pollut. 2021, 272, 115923. [CrossRef]

42. Santos, A.A.; Guedes, D.O.; Barros, M.U.G.; Oliveira, S.; Pacheco, A.B.F.; Azevedo, S.M.F.O.; Magalhães, V.F.; Pestana, C.J.; Edwards, C.; Lawton, L.A.; et al. Effect of hydrogen peroxide on natural phytoplankton and bacterioplankton in a drinking water reservoir: Mesocosm-scale study. Water Res. 2021, 197, 117069. [CrossRef]

43. Matthijs, H.C.P.; Visser, P.M.; Reeze, B.; Meeuse, J.; Slot, P.C.; Wijn, G.; Talens, R.; Huisman, J. Selective suppression of harmful cyanobacteria in an entire lake with hydrogen peroxide. Water Res. 2012, 46, 1460-1472. [CrossRef]

44. Barrington, D.J.; Reichwaldt, E.S.; Ghadouani, A. The use of hydrogen peroxide to remove cyanobacteria and microcystins from waste stabilization ponds and hypereutrophic systems. Ecol. Eng. 2013, 50, 86-94. [CrossRef]

45. Burson, A.; Matthijs, H.C.P.; de Bruijne, W.; Talens, R.; Hoogenboom, R.; Gerssen, A.; Visser, P.M.; Stomp, M.; Steur, K.; van Scheppingen, Y.; et al. Termination of a toxic Alexandrium bloom with hydrogen peroxide. Harmful Algae 2014, 31, 125-135. [CrossRef]

46. Lück, E.; Jager, M. Antimicrobial Food Additives: Characteristics, Uses, Effects; Springer: Berlin, Germany, $1997 ;$ Volume 2.

47. Bjarnsholt, T.; Jensen, P.Ø.; Burmølle, M.; Hentzer, M.; Haagensen, J.A.J.; Hougen, H.P.; Calum, H.; Madsen, K.G.; Moser, C.; Molin, S.; et al. Pseudomonas aeruginosa tolerance to tobramycin, hydrogen peroxide and polymorphonuclear leukocytes is quorum-sensing dependent. Microbiology 2005, 151, 373-383. [CrossRef]

48. Sultana, S.T.; Atci, E.; Babauta, J.T.; Falghoush, A.M.; Snekvik, K.R.; Call, D.R.; Beyenal, H. Electrochemical scaffold generates localized, low concentration of hydrogen peroxide that inhibits bacterial pathogens and biofilms. Sci. Rep. 2015, 5, 14908. [CrossRef] [PubMed]

49. Ohwada, T.; Shirakawa, Y.; Kusumoto, M.; Masuda, H.; Sato, T. Susceptibility to hydrogen peroxide and catalase activity of root nodule bacteria. Biosci. Biotechnol. Biochem. 1999, 63, 457-462. [CrossRef]

50. Zhao, Y.; Nickels, L.M.; Wang, H.; Ling, J.; Zhong, Z.; Zhu, J. OxyR-regulated catalase activity is critical for oxidative stress resistance, nodulation and nitrogen fixation in Azorhizobium caulinodans. FEMS Microbiol. Lett. 2016, 363, fnw130. [CrossRef] [PubMed]

51. Strus, M.; Brzychczy-Włoch, M.; Gosiewski, T.; Kochan, P.; Heczko, P.B. The in vitro effect of hydrogen peroxide on vaginal microbial communities. FEMS Immunol. Med. Microbiol. 2006, 48, 56-63. [CrossRef] [PubMed]

52. Zhu, L.; Kreth, J. The role of hydrogen peroxide in environmental adaptation of oral microbial communities. Oxid. Med. Cell. Longev. 2012, 2012, 1-10. [CrossRef] [PubMed]

53. Xenopoulos, M.A.; Bird, D.F. Effect of acute exposure to hydrogen peroxide on the production of phytoplankton and bacterioplankton in a mesohumic lake. Photochem. Photobiol. 1997, 66, 471-478. [CrossRef]

54. Kakosová, E.; Hrabák, P.; Černík, M.; Novotný, V.; Czinnerová, M.; Trögl, J.; Popelka, J.; Kuráň, P.; Zoubková, L.; Vrtoch, L'. Effect of various chemical oxidation agents on soil microbial communities. Chem. Eng. J. 2017, 314, 257-265. [CrossRef]

55. Newton, R.J.; Jones, S.E.; Eiler, A.; McMahon, K.D.; Bertilsson, S. A guide to the natural history of freshwater lake bacteria. Microbiol. Mol. Biol. Rev. 2011, 75, 14-49. [CrossRef]

56. Linz, A.M.; He, S.; Stevens, S.L.R.; Anantharaman, K.; Rohwer, R.R.; Malmstrom, R.R.; Bertilsson, S.; McMahon, K.D. Freshwater carbon and nutrient cycles revealed through reconstructed population genomes. PeerJ 2018, 6, e6075. [CrossRef] [PubMed]

57. Lu, C.P.; Lin, C.T.; Chang, C.M.; Wu, S.H.; Lo, L.C. Nitrophenylboronic acids as highly chemoselective probes to detect hydrogen peroxide in foods and agricultural products. J. Agric. Food Chem. 2011, 59, 11403-11406. [CrossRef] [PubMed]

58. Utermöhl, H. Zur Vervollkommnung Der Quantitativen Phytoplankton-Methodik: Mit 1 Tabelle Und 15 Abbildungen Im Text Und Auf 1 Tafel. Int. Ver. Theor. Angew. Limnol. Mitt. 1958, 9, 1-38. [CrossRef]

59. Hillebrand, H.; Dürselen, C.-D.; Kirschtel, D.; Pollingher, U.; Zohary, T. Biovolume calculation for pelagic and benthic microalgae. J. Phycol. 1999, 35, 403-424. [CrossRef]

60. Marie, D.; Partensky, F.; Vaulot, D.; Brussaard, C. Enumeration of phytoplankton, bacteria, and viruses in marine samples. Curr. Protoc. Cytom. 1999, 10, 11. [CrossRef] [PubMed]

61. Chelius, M.K.; Triplett, E.W. The diversity of Archaea and Bacteria in association with the roots of Zea mays L. Microb. Ecol. 2001, 41, 252-263. [CrossRef]

62. Bodenhausen, N.; Horton, M.W.; Bergelson, J. Bacterial communities associated with the leaves and the roots of Arabidopsis thaliana. PLoS ONE 2013, 8, e56329. [CrossRef]

63. Bolyen, E.; Rideout, J.R.; Dillon, M.R.; Bokulich, N.A.; Abnet, C.C.; Al-Ghalith, G.A.; Alexander, H.; Alm, E.J.; Arumugam, M.; Asnicar, F.; et al. Reproducible, interactive, scalable and extensible microbiome data science using QIIME 2. Nat. Biotechnol. 2019, 37, 852-857. [CrossRef]

64. Hamady, M.; Walker, J.J.; Harris, J.K.; Gold, N.J.; Knight, R. Error-correcting barcoded primers allow hundreds of samples to be pyrosequenced in multiplex. Nat. Methods 2008, 5, 235-237. [CrossRef] [PubMed]

65. Hamady, M.; Knight, R. Microbial community profiling for human microbiome projects: Tools, techniques, and challenges. Genome Res. 2009, 19, 1141-1152. [CrossRef] [PubMed] 
66. Callahan, B.J.; McMurdie, P.J.; Rosen, M.J.; Han, A.W.; Johnson, A.J.A.; Holmes, S.P. DADA2: High-resolution sample inference from Illumina amplicon data. Nat. Methods 2016, 13, 581-583. [CrossRef] [PubMed]

67. Bokulich, N.A.; Kaehler, B.D.; Rideout, J.R.; Dillon, M.; Bolyen, E.; Knight, R.; Huttley, G.A.; Caporaso, J.G. Optimizing taxonomic classification of marker-gene amplicon sequences with QIIME 2's q2-feature-classifier plugin. Microbiome 2018, 6, 1-17. [CrossRef]

68. Pedregosa, F.; Varoquaux, G.; Gramfort, A.; Michel, V.; Thirion, B.; Grisel, O.; Blondel, M.; Prettenhofer, P.; Weiss, R.; Dubourg, V.; et al. Scikit-learn: Machine learning in Python. J. Mach. Learn. Res. 2011, 12, 2825-2830.

69. Quast, C.; Pruesse, E.; Yilmaz, P.; Gerken, J.; Schweer, T.; Yarza, P.; Peplies, J.; Glöckner, F.O. The SILVA ribosomal RNA gene database project: Improved data processing and web-based tools. Nucleic Acids Res. 2013, 41, D590-D596. [CrossRef]

70. Yilmaz, P.; Parfrey, L.W.; Yarza, P.; Gerken, J.; Pruesse, E.; Quast, C.; Schweer, T.; Peplies, J.; Ludwig, W.; Glöckner, F.O. The SILVA and "All-Species Living Tree Project (LTP)" taxonomic frameworks. Nucleic Acids Res. 2014, 42, D643-D648. [CrossRef]

71. Janssen, S.; Mcdonald, D.; Gonzalez, A.; Navas-Molina, J.A.; Jiang, L.; Xu, Z.Z.; Winker, K.; Kado, D.M.; Orwoll, E.; Manary, M.; et al. Phylogenetic placement of exact amplicon sequences improves associations with clinical information. mSystems 2018, 3, e00021. [CrossRef]

72. Weiss, S.; Xu, Z.Z.; Peddada, S.; Amir, A.; Bittinger, K.; Gonzalez, A.; Lozupone, C.; Zaneveld, J.R.; Vázquez-Baeza, Y.; Birmingham, A.; et al. Normalization and microbial differential abundance strategies depend upon data characteristics. Microbiome 2017, 5, 27. [CrossRef]

73. Bray, J.R.; Curtis, J.T. An ordination of the upland forest communities of southern Wisconsin. Ecol. Monogr. 1957, 27, 325-349. [CrossRef]

74. Lozupone, C.; Knight, R. UniFrac: A new phylogenetic method for comparing microbial communities. Appl. Environ. Microbiol. 2005, 71, 8228-8235. [CrossRef]

75. Lozupone, C.A.; Hamady, M.; Kelley, S.T.; Knight, R. Quantitative and qualitative $\beta$ diversity measures lead to different insights into factors that structure microbial communities. Appl. Environ. Microbiol. 2007, 73, 1576-1585. [CrossRef] [PubMed]

76. Chang, Q.; Luan, Y.; Sun, F. Variance Adjusted Weighted UniFrac: A powerful beta diversity measure for comparing communities based on phylogeny. BMC Bioinform. 2011, 12, 118. [CrossRef] [PubMed]

77. Chen, J.; Bittinger, K.; Charlson, E.S.; Hoffmann, C.; Lewis, J.; Wu, G.D.; Collman, R.G.; Bushman, F.D.; Li, H. Associating microbiome composition with environmental covariates using generalized UniFrac distances. Bioinformatics 2012, 28, $2106-2113$. [CrossRef] [PubMed]

78. McDonald, D.; Vázquez-Baeza, Y.; Koslicki, D.; McClelland, J.; Reeve, N.; Xu, Z.; Gonzalez, A.; Knight, R. Striped UniFrac: Enabling microbiome analysis at unprecedented scale. Nat. Methods 2018, 15, 847-848. [CrossRef]

79. Anderson, M.J. A new method for non-parametric multivariate analysis of variance. Austral Ecol. 2001, 26, 32-46. [CrossRef]

80. Gloor, G.B.; Macklaim, J.M.; Pawlowsky-Glahn, V.; Egozcue, J.J. Microbiome datasets are compositional: And this is not optional. Front. Microbiol. 2017, 8, 2224. [CrossRef]

81. Fernandes, A.D.; Macklaim, J.M.; Linn, T.G.; Reid, G.; Gloor, G.B. ANOVA-like differential expression (ALDEx) analysis for mixed population RNA-Seq. PLoS ONE 2013, 8, e67019. [CrossRef]

82. Fernandes, A.D.; Reid, J.N.S.; Macklaim, J.M.; McMurrough, T.A.; Edgell, D.R.; Gloor, G.B. Unifying the analysis of highthroughput sequencing datasets: Characterizing RNA-Seq, 16S rRNA gene sequencing and selective growth experiments by compositional data analysis. Microbiome 2014, 2, 15. [CrossRef]

83. Guevara Campoverde, N.C.; Hassenrück, C.; Buttigieg, P.L.; Gärdes, A. Characterization of bacterioplankton communities and quantification of organic carbon pools off the Galapagos Archipelago under contrasting environmental conditions. Peer $\mathbf{2 0 1 8 ,}$ 6, e5984. [CrossRef]

84. Fernandes, A.D.; Vu, M.T.H.Q.; Edward, L.-M.; Macklaim, J.M.; Gloor, G.B. A reproducible effect size is more useful than an irreproducible hypothesis test to analyze high throughput sequencing datasets. arXiv 2018, arXiv:1809.02623.

85. Benjamini, Y.; Hochberg, Y. Controlling the false discovery rate: A practical and powerful approach to multiple testing. J. R. Stat. Soc. Ser. B 1995, 57, 289-300. [CrossRef]

86. Douglas, G.M.; Maffei, V.J.; Zaneveld, J.R.; Yurgel, S.N.; Brown, J.R.; Taylor, C.M.; Huttenhower, C.; Langille, M.G.I. PICRUSt2 for prediction of metagenome functions. Nat. Biotechnol. 2020, 38, 685-688. [CrossRef] [PubMed]

87. Wemheuer, F.; Taylor, J.A.; Daniel, R.; Johnston, E.; Meinicke, P.; Thomas, T.; Wemheuer, B. Tax4Fun2: Prediction of habitat-specific functional profiles and functional redundancy based on $16 \mathrm{~S}$ rRNA gene sequences. Environ. Microbiome 2020, 15, 11. [CrossRef] [PubMed]

88. Lombard, V.; Golaconda Ramulu, H.; Drula, E.; Coutinho, P.M.; Henrissat, B. The carbohydrate-active enzymes database (CAZy) in 2013. Nucleic Acids Res. 2014, 42, D490-D495. [CrossRef] [PubMed]

89. Kanehisa, M.; Goto, S. KEGG: Kyoto Encyclopedia of Genes and Genomes. Nucleic Acids Res. 2000, 28, 27-30. [CrossRef]

90. Kanehisa, M.; Sato, Y.; Furumichi, M.; Morishima, K.; Tanabe, M. New approach for understanding genome variations in KEGG. Nucleic Acids Res. 2019, 47, D590-D595. [CrossRef]

91. Kanehisa, M. Toward understanding the origin and evolution of cellular organisms. Protein Sci. 2019, 28, 1947-1951. [CrossRef]

92. Lürling, M.; Mucci, M.; Waajen, G. Removal of positively buoyant Planktothrix rubescens in lake restoration. Toxins 2020, 12, 700. [CrossRef] [PubMed]

93. Schuurmans, J.M.; Brinkmann, B.W.; Makower, A.K.; Dittmann, E.; Huisman, J.; Matthijs, H.C.P. Microcystin interferes with defense against high oxidative stress in harmful cyanobacteria. Harmful Algae 2018, 78, 47-55. [CrossRef] 
94. Heaney, S.I.; Furnass, T.I. Laboratory models of diel vertical migration in the dinoflagellate Ceratium hirundinella. Freshw. Biol. 1980, 10, 163-170. [CrossRef]

95. Arndt, H. Rotifers as predators on components of the microbial web (bacteria, heterotrophic flagellates, ciliates): A review. Hydrobiologia 1993, 255/256, 231-246. [CrossRef]

96. Agasild, H.; Nõges, T. Cladoceran and rotifer grazing on bacteria and phytoplankton in two shallow eutrophic lakes: In situ measurement with fluorescent microspheres. J. Plankton Res. 2005, 27, 1155-1174. [CrossRef]

97. Hwang, S.-J.; Heath, R.T. Zooplankton bacterivory at coastal and offshore sites of Lake Erie. J. Plankton Res. 1999, $21,699-719$. [CrossRef]

98. Eiler, A.; Bertilsson, S. Composition of freshwater bacterial communities associated with cyanobacterial blooms in four Swedish lakes. Environ. Microbiol. 2004, 6, 1228-1243. [CrossRef] [PubMed]

99. Wang, K.; Razzano, M.; Mou, X. Cyanobacterial blooms alter the relative importance of neutral and selective processes in assembling freshwater bacterioplankton community. Sci. Total Environ. 2020, 706, 135724. [CrossRef]

100. Shade, A.; Read, J.S.; Youngblut, N.D.; Fierer, N.; Knight, R.; Kratz, T.K.; Lottig, N.R.; Roden, E.E.; Stanley, E.H.; Stombaugh, J.; et al. Lake microbial communities are resilient after a whole-ecosystem disturbance. ISME J. 2012, 6, 2153-2167. [CrossRef]

101. Glaeser, S.P.; Berghoff, B.A.; Stratmann, V.; Grossart, H.P.; Glaeser, J. Contrasting effects of singlet oxygen and hydrogen peroxide on bacterial community composition in a humic lake. PLoS ONE 2014, 9, e92518. [CrossRef]

102. Woodhouse, J.N.; Kinsela, A.S.; Collins, R.N.; Bowling, L.C.; Honeyman, G.L.; Holliday, J.K.; Neilan, B.A. Microbial communities reflect temporal changes in cyanobacterial composition in a shallow ephemeral freshwater lake. ISME J. 2016, 10, 1337-1351. [CrossRef]

103. Diao, M.; Sinnige, R.; Kalbitz, K.; Huisman, J.; Muyzer, G. Succession of bacterial communities in a seasonally stratified lake with an anoxic and sulfidic hypolimnion. Front. Microbiol. 2017, 8, 2511. [CrossRef] [PubMed]

104. Su, X.; Steinman, A.D.; Tang, X.; Xue, Q.; Zhao, Y.; Xie, L. Response of bacterial communities to cyanobacterial harmful algal blooms in Lake Taihu, China. Harmful Algae 2017, 68, 168-177. [CrossRef] [PubMed]

105. Poretsky, R.; Rodriguez, -R.L.M.; Luo, C.; Tsementzi, D.; Konstantinidis, K.T. Strengths and limitations of 16S rRNA gene amplicon sequencing in revealing temporal microbial community dynamics. PLoS ONE 2014, 9, e93827. [CrossRef]

106. Chen, W.M.; Lin, C.Y.; Sheu, S.Y. Investigating antimicrobial activity in Rheinheimera sp. due to hydrogen peroxide generated by L-lysine oxidase activity. Enzym. Microb. Technol. 2010, 46, 487-493. [CrossRef]

107. Chang, W.; Small, D.A.; Toghrol, F.; Bentley, W.E. Microarray analysis of Pseudomonas aeruginosa reveals induction of pyocin genes in response to hydrogen peroxide. BMC Genom. 2005, 6, 115. [CrossRef]

108. Kiley, P.J.; Kaplan, S. Molecular genetics of photosynthetic membrane biosynthesis in Rhodobacter sphaeroides. Microbiol. Rev. 1988, 52, 50-69. [CrossRef] [PubMed]

109. Tabita, F.R. The biochemistry and metabolic regulation of carbon metabolism and $\mathrm{CO}_{2}$ fixation in purple bacteria. In Anoxygenic Photosynthetic Bacteria. Advances in Photosynthesis ad Respiration; Blankenship, R.E., Madigan, M.T., Bauer, C.E., Eds.; Kluwer Academic Publishers: Dordrecht, The Netherlands, 1995; pp. 885-914.

110. Satoh, T.; Hoshino, Y.; Kitamura, H. Rhodopseudomonas sphaeroides forma sp. denitrificans, a denitrifying strain as a subspecies of Rhodopseudomonas sphaeroides. Arch. Microbiol. 1976, 108, 265-269. [CrossRef] [PubMed]

111. Sangwan, P.; Chen, X.; Hugenholtz, P.; Janssen, P.H. Chthoniobacter flavus gen. nov., sp. nov., the first pure-culture representative of subdivision two, Spartobacteria classis nov., of the phylum Verrucomicrobia. Appl. Environ. Microbiol. 2004, 70, 5875-5881. [CrossRef] [PubMed]

112. Chiang, E.; Schmidt, M.L.; Berry, M.A.; Biddanda, B.A.; Burtner, A.; Johengen, T.H.; Palladino, D.; Denef, V.J. Verrucomicrobia are prevalent in north-temperate freshwater lakes and display class-level preferences between lake habitats. PLoS ONE 2018, 13, e0195112. [CrossRef]

113. Herlemann, D.P.R.; Lundin, D.; Labrenz, M.; Jürgens, K.; Zheng, Z.; Aspeborg, H.; Andersson, A.F. Metagenomic de novo assembly of an aquatic representative of the Verrucomicrobial class Spartobacteria. mBio 2013, 4, e00569. [CrossRef]

114. He, S.; Stevens, S.L.R.; Chan, L.-K.; Bertilsson, S.; Glavina del Rio, T.; Tringe, S.G.; Malmstrom, R.R.; McMahon, K.D. Ecophysiology of freshwater Verrucomicrobia inferred from metagenome-assembled genomes. mSphere 2017, 2, e00277. [CrossRef] [PubMed]

115. Allison, S.D.; Martiny, J.B.H. Resistance, resilience, and redundancy in microbial communities. Proc. Natl. Acad. Sci. USA 2008, 105, 11512-11519. [CrossRef] [PubMed]

116. Teeling, H.; Fuchs, B.M.; Becher, D.; Klockow, C.; Gardebrecht, A.; Bennke, C.M.; Kassabgy, M.; Huang, S.; Mann, A.J.; Waldmann, J.; et al. Substrate-controlled succession of marine bacterioplankton populations induced by a phytoplankton bloom. Science 2012, 336, 608-611. [CrossRef]

117. Berry, M.A.; Davis, T.W.; Cory, R.M.; Duhaime, M.B.; Johengen, T.H.; Kling, G.W.; Marino, J.A.; den Uyl, P.A.; Gossiaux, D.; Dick, G.J.; et al. Cyanobacterial harmful algal blooms are a biological disturbance to western Lake Erie bacterial communities. Environ. Microbiol. 2017, 19, 1149-1162. [CrossRef] [PubMed]

118. Bender, E.A.; Case, T.J.; Gilpin, M.E. Perturbation experiments in community ecology: Theory and practice. Ecology 1984, 65, 1-13. [CrossRef]

119. Shade, A.; Peter, H.; Allison, S.D.; Baho, D.L.; Berga, M.; Bürgmann, H.; Huber, D.H.; Langenheder, S.; Lennon, J.T.; Martiny, J.B.H.; et al. Fundamentals of microbial community resistance and resilience. Front. Microbiol. 2012, 3, 417. [CrossRef] 
120. Shade, A.; Read, J.S.; Welkie, D.G.; Kratz, T.K.; Wu, C.H.; McMahon, K.D. Resistance, resilience and recovery: Aquatic bacterial dynamics after water column disturbance. Environ. Microbiol. 2011, 13, 2752-2767. [CrossRef]

121. Baho, D.L.; Peter, H.; Tranvik, L.J. Resistance and resilience of microbial communities: Temporal and spatial insurance against perturbations. Environ. Microbiol. 2012, 14, 2283-2292. [CrossRef]

122. Daehler, C.C.; Strong, D.R. Status, prediction and prevention of introduced cordgrass Spartina spp. invasions in Pacific estuaries, USA. Biol. Conserv. 1996, 78, 51-58. [CrossRef]

123. Louca, S.; Jacques, S.M.S.; Pires, A.P.F.; Leal, J.S.; Srivastava, D.S.; Parfrey, L.W.; Farjalla, V.F.; Doebeli, M. High taxonomic variability despite stable functional structure across microbial communities. Nat. Ecol. Evol. 2017, 1, 15. [CrossRef]

124. Xu, Z.; Malmer, D.; Langille, M.G.I.; Way, S.F.; Knight, R. Which is more important for classifying microbial communities: Who's there or what they can do? ISME J. 2014, 8, 2357-2359. [CrossRef]

125. Koo, H.; Hakim, J.A.; Morrow, C.D.; Eipers, P.G.; Davila, A.; Andersen, D.T.; Bej, A.K. Comparison of two bioinformatics tools used to characterize the microbial diversity and predictive functional attributes of microbial mats from Lake Obersee, Antarctica. J. Microbiol. Methods 2017, 140, 15-22. [CrossRef]

126. Jankowiak, J.G.; Gobler, C.J. The composition and function of microbiomes within Microcystis colonies are significantly different than native bacterial assemblages in two North American lakes. Front. Microbiol. 2020, 11, 1016. [CrossRef] [PubMed]

127. Wan, W.; Zhang, Y.; Cheng, G.; Li, X.; Qin, Y.; He, D. Dredging mitigates cyanobacterial bloom in eutrophic Lake Nanhu: Shifts in associations between the bacterioplankton community and sediment biogeochemistry. Environ. Res. 2020, 188, 109799. [CrossRef] [PubMed]

128. Zhou, S.; Sun, Y.; Yu, M.; Shi, Z.; Zhang, H.; Peng, R.; Li, Z.; Cui, J.; Luo, X. Linking shifts in bacterial community composition and function with changes in the dissolved organic matter pool in ice-covered Baiyangdian Lake, northern China. Microorganisms 2020, 8, 883. [CrossRef] [PubMed]

129. Mishra, S.; Imlay, J. Why do bacteria use so many enzymes to scavenge hydrogen peroxide? Arch. Biochem. Biophys. 2012, 525, 145-160. [CrossRef]

130. Andrade, A.C.; Fróes, A.; Lopes, F.Á.C.; Thompson, F.L.; Krüger, R.H.; Dinsdale, E.; Bruce, T. Diversity of microbial carbohydrateactive enzymes (Cazymes) associated with freshwater and soil samples from Caatinga biome. Microb. Ecol. 2017, $74,89-105$. [CrossRef] 